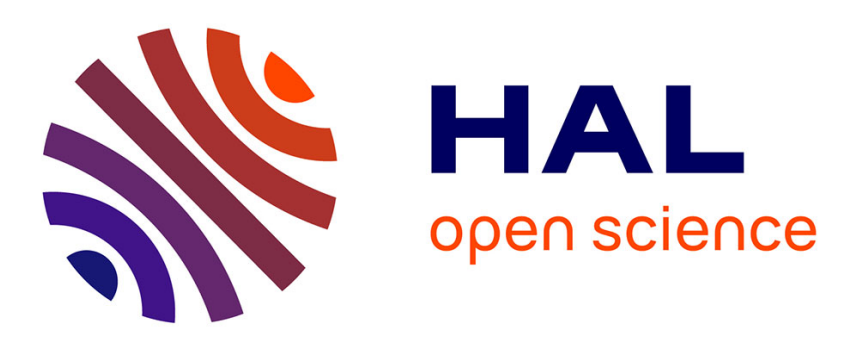

\title{
Compressive behaviour of axially loaded spruce wood under large deformations at different strain rates
}

Martin Neumann, Jürgen Herter, Bernhard O. Droste, Sylvius Hartwig

\section{To cite this version:}

Martin Neumann, Jürgen Herter, Bernhard O. Droste, Sylvius Hartwig. Compressive behaviour of axially loaded spruce wood under large deformations at different strain rates. European Journal of Wood and Wood Products, 2010, 69 (3), pp.345-357. 10.1007/s00107-010-0442-x . hal-00615336

\section{HAL Id: hal-00615336 https://hal.science/hal-00615336}

Submitted on 19 Aug 2011

HAL is a multi-disciplinary open access archive for the deposit and dissemination of scientific research documents, whether they are published or not. The documents may come from teaching and research institutions in France or abroad, or from public or private research centers.
L'archive ouverte pluridisciplinaire HAL, est destinée au dépôt et à la diffusion de documents scientifiques de niveau recherche, publiés ou non, émanant des établissements d'enseignement et de recherche français ou étrangers, des laboratoires publics ou privés. 
Ejwwp442_source

\title{
Compressive behaviour of axially loaded spruce wood under large deformations at different strain rates
}

\section{Verhalten von axial beanspruchtem}

\section{Fichtenholz unter Druckbeanspruchung bei großen Deformationen und verschiedenen Dehnraten}

\author{
Martin Neumann $^{\mathrm{a}}$, Jürgen Herter ${ }^{\mathrm{a}}$, Bernhard O. Droste ${ }^{\mathrm{a}}$, Sylvius Hartwig ${ }^{\mathrm{b}}$ \\ ${ }^{a}$ BAM Federal Institute for Materials Research and Testing, 12200 Berlin, \\ Germany \\ ${ }^{b}$ Bergische Universität Wuppertal, HS Furtwangen, Germany \\ martin.neumann@bam.de
}

\begin{abstract}
Impact limiting components of packages for the transport of radioactive materials are often designed as wood filled steel constructions. Wood absorbs major part of the impact energy in order to minimize the impact load acting upon the containment. Dynamic impact experiments with wood filled impact limiters showed different crushing mechanisms for axially loaded wood depending on their lateral constraint. Tests on spruce wood samples (Picea abies) were performed in order to clarify the influence of strain rate from static to $30 \mathrm{~s}^{-1}$ on a) compression strength, b) stress at a global strain level of 50\%, and c) energy absorption capacity at 50\% deformation, including statistical evaluation of the results. Results were as follows: strain rate increase led to significantly higher compression strength, stress and strain energy at a strain level of 50\%. Lateral strain restriction had no effect on compression strength; it had a significant effect on stress and strain energy at strain level of $50 \%$. Therefore, the definition of a general yield curve for wood under large deformations is not possible, the yield curve has to be chosen taking into account lateral constraints.
\end{abstract}

\section{Zusammenfassung}

Stoßdämpfende Bauteile von Transportbehältern für radioaktive Stoffe sind oft als holzgefüllte Stahlkonstruktionen konstruiert. Um die Stoßbeanspruchung der dichten Umschließung zu minimieren, absorbiert das Holz einen Großteil der Aufprallenergie. Fallversuche mit 


\section{Ejwwp442_source}

stoßdämpfenden Bauteilen haben gezeigt, dass abhängig von seitlicher Dehnungsbehinderung unterschiedliche Kompressionsmechanismen für axial beanspruchtes Holz ersichtlich waren. Versuche mit Fichtenholzproben (Picea abies) wurden durchgeführt, um mit Hilfe statistischer Methoden den Einfluss der Dehnrate von statisch bis $30 \mathrm{~s}^{-1}$ auf a) Druckfestigkeit, b) Spannung bei globaler Stauchung von 50\% und c) Energieabsorption bei einer Stauchung von 50\% zu ermitteln. Folgende Resultate wurden erzielt: Eine höhere Dehnrate führte zu signifikant höheren Druckfestigkeiten, Druckspannungen und Energieabsorptionen bei 50\% Stauchung. Die seitliche Dehnungsbehinderung hatte keinen Einfluss auf die Druckfestigkeit, mit seitlicher Dehnungsbehinderung zeigten sich aber signifikant erhöhte Druckspannungen und Energieabsorptionen bei 50\% Stauchung. Daher ist die Definition einer allgemeingültigen Fließkurve für Holz bei großen Deformationen nicht möglich, die Fließkurve muss unter Einbeziehung der seitlichen Dehnungsbehinderung gewählt werden. 
Ejwwp442_source

\section{Introduction}

The BAM Federal Institute for Materials Research and Testing is the German government institute responsible for the mechanical and thermal safety assessment of transport casks for radioactive material as required by the IAEA Regulations (IAEA 2005, 2008). The mechanical tests to be performed according to IAEA Regulations include, among others, a $9 \mathrm{~m}$ free drop test onto an unyielding target in order to demonstrate safety under hypothetical accident conditions. Energy absorbing cask components are used to transform kinetic energy to plastic deformation energy over an appropriate long drop impact time and deformation path. Longer impact time and higher deformation lead to a reduction of the maximum impact load. In most cases impact limiting components are wood-filled steel casing constructions, which are bolted to the cask body. By applying large volumes of spruce-wood, the necessary energy absorption capacity is allocated for existing masses and dimensions of transport packages. In the process of energy absorption the wood, mostly aligned in axial direction, is crushed up to large strains. Since it is important to specify the energy absorption capacity of impact limiting devices in analysis of transport casks, compressive behaviour and energy absorbing capacity of axially loaded wood under large deformations are of major interest.

\section{Wood behaviour under mechanical stress}

Wood on a macroscopic level can be divided into bark, cambium, sapwood, heartwood, pith and wood rays (Forest Products Laboratory 1999). Year rings are visible for most woods in temperate climates. They are zones formed by earlyand latewood within a growing season. Wood is macroscopically mainly considered an orthotropic material with three main directions "axial" along the stem (a), "radial" perpendicular to the year rings (r) and tangential along the year rings (t) (Dinwoodie 2000; Forest Products Laboratory 1999; Gibson and Ashby 1997; Niemz 1993). On a microscopic level, wood has a cellular structure. The wood cells, called tracheids, are the structural elements of wood tissue. They are elongated and towards the ends often pitched cells that are mostly aligned with the stem (Fengel and Wegener 1989). On even smaller scale wood can be understood 
Ejwwp442_source

as fibre reinforced composite, where lignin is the matrix, and cellulose can be understood as the fibre (Bodig and Jayne 1982; Niemz 1993).

Regarding mechanical properties, published work focuses on the elastic region or small plastic deformations until reaching compressive strength. A wide range of studies concerning the elastic properties and elastic compression mechanisms of wood has been published (Dinwoodie 2000; Grimsel 1999; Grosse 2005; Hermanson 1996; Kollmann 1936; Niemz 1993; Poulsen 1997). Works on wood failure mechanisms under compression include Bariska and Kucera (1985), Bodig, (1966), DeBaise et al. (1966), Easterling et al. (1982), Gindl (2002), Gong and Smith (2000), Grosse (2005), Müller (2003), Poulsen (1997), Smith and Vasic (2003), Tabarsa and Chui (2001). The underlying fracture criteria have been investigated by Daudeville (1999), Eberhardsteiner (2002) and Mackenzie-Helnwein et al. (2003). Different angles to the grain have been investigated by Reiterer and Stanzl-Tschegg (2001). Further publications deal with special aspects like influence of temperature and moisture content (Bodig and Jayne 1982; Hamdan et al. 2000; Kollmann 1982; Mascia and Cramer 2000; Niemz 1993; Seborg and Stamm 1941), size effects (Dill-Langer et al. 2003; Schneeweiss 1963) and creep dependency (Keith 1972).

Strain rate effects have been investigated by Reid and Peng (1997) and Vural and Ravichandran (2003). Both studies were performed with Split Hopkinson Bars and deal therefore with large impact velocities and strain rates up to $50001 / \mathrm{s}$. The impact velocity for $9 \mathrm{~m}$ drop tests with casks for radioactive material equals $13.3 \mathrm{~m} / \mathrm{s}$ resulting in initial strain rates of about $20-40 \mathrm{~s}^{-1}$ (corresponds to wood thicknesses ranging from $330 \mathrm{~mm}$ to $660 \mathrm{~mm}$ ). The published results do not allow a quantification of the influence for strain rates around 20-40 $\mathrm{s}^{-1}$ against static tests.

Information about compression under large deformations for wood has been published by Adalian and Morlier (2002), Easterling et al. (1982), Gibson and Ashby (1997). All studies show a "lock-up" (Fig 1) (Gibson and Ashby 1999) after reaching a certain wood-dependent strain, where the tracheids are fully compressed and compressed wood behaves like cell wall material. Therefore, it hardens significantly. Furthermore, all studies reveal a softening behaviour of axially compressed wood, but plateau stress (stress after reaching compression strength) in stress-strain-curves (Fig 1) is presented as universally valid. 
Ejwwp442_source

\section{Wood behaviour in impact limiter}

An analysis of wood filled impact limiter after drop tests with casks for radioactive material shows different compression characteristics for axially loaded wood depending on the zone in the impact limiter.

At the beginning of compression all zones in the impact limiter show comparable response mechanisms. After the elastic range compression strength is reached and wood fibre bundles buckle after lateral tensile failure (Fig 3). The number of buckle-points is not constant. An apparent transversal elongation is visible. In subsequent deformation, energy absorption mechanisms differ depending on the position of wood in the impact limiter. Mostly axially compressed wood can be found in the main impact zone of the impact limiter (B Fig 2), where wood is crushed directly between cask and target. Wood in this area shows a large number of local buckling spots. Due to a lateral confinement from surrounded wood, it is mainly compressed in axial direction, and therefore it can be assumed that absorbed energy is relatively large (Fig 4).

Wood is laterally little restricted in zones that lie on the brink of the impact limiter (Fig 5). Wood fibres in this region can, after macroscopic lateral tensile failure (Grosse 2005), evade from axial compression. Wood fibres buckle less frequent and are afterwards compressed to a larger extent in transversal directions (Fig 5). Although zone location in the impact limiter alters with different impact limiter construction, the different principles of energy absorption have been found on all analysed impact limiters (Musolff et al. 2008; Quercetti et al. 2008).

\section{Work scope}

The topic of strain rate dependency of mechanical properties of wood under large deformations has not been addressed yet. Although it is generally understood that higher strain rates lead to higher strengths (Reid and Peng 1997) the influence is difficult to estimate due to the - compared to earlier tests (Reid and Peng 1997; Vural and Ravichandran 2003) - relatively low strain rate of up to $40 \mathrm{~s}^{-1}$ for impact scenarios with casks.

The influence of lateral strain restriction on energy absorption capacity of wood has not been identified yet. Results from analysis of impact limiter wood indicate that lateral strain restriction increases energy absorption capacity for axially loaded wood. The influence is of major importance since the amount of energy 
Ejwwp442_source

which can be absorbed by the impact limiter has to be specified correctly.

Extensive impact limiter compression has to be ruled out since it leads to very high impact loads in the cask.

The following experimental investigation should therefore identify

1. the influence of strain rate on compression strength at strain rates from static to $301 / \mathrm{s}$

2. the influence of strain rate on absorbed energy at high deformations at strain rates from static to $301 / \mathrm{s}$

3. whether different lateral constraints have an influence on the energy absorption capacity of axially loaded wood.

\section{Materials and Methods}

\section{Materials}

The material used in this investigation was spruce-wood (Picea abies) of German production. The samples were made from wood of grade S10 (DIN4074-1 2008) with a moisture content of $15 \pm 3 \%$. This equals strength class $\mathrm{C} 24$ according to DIN EN 338 (2008). The densities varied in a range from 400 till $450 \mathrm{~kg} / \mathrm{m}^{3}$. The wood was without major macroscopic defects like knots or cracks.

Tabarsa and Chui (2001) proposed cube shaped specimens of $8 \mathrm{~mm}$ length, while in DIN 52185 (1976) an ashlar shaped specimen with dimensions of $20 \mathrm{~mm} \mathrm{x}$ $20 \mathrm{~mm} \times 50 \mathrm{~mm}$ is proposed. However, this geometry is proposed for static tests. The fibre arrangement and resulting failure mechanisms in the case of this study were to be as close as possible to the application in the impact limiters for tests with large deformations. Due to the available test equipment a minimum sample height of $100 \mathrm{~mm}$ was necessary in order to ensure a constant crushing speed. Therefore cube shaped specimens with $100 \mathrm{~mm}$ edge length (Fig 6) were chosen. The samples were consecutively numbered (Fig 6). They were arranged and named in groups according to impact speed $(0.001 \mathrm{~m} / \mathrm{s}, 0.3 \mathrm{~m} / \mathrm{s}$ and $3.0 \mathrm{~m} / \mathrm{s}$, initial strain rate $0.01 \mathrm{~s}^{-1}, 3.0 \mathrm{~s}^{-1}$ and $30 \mathrm{~s}^{-1}$ ), loading direction (1 for axial and $\mathrm{q}$ for transversal oriented wood) and lateral constraint ( $\mathrm{m}$ with constraint and o without constraint). Hence, e.g. ol3000 is the sample group without lateral strain restriction, loaded axially at $3.0 \mathrm{~m} / \mathrm{s}$. 
Ejwwp442_source

\section{Methods}

\section{Test equipment}

The servo-hydraulic $1000 \mathrm{kN}$ impact test facility (Fig 7) (BAM, 2009) was developed in order to investigate the behaviour of components under impact load, notably e.g. an impact of an aircraft on the reinforced concrete structure of a nuclear power plant containment. The maximum tensile or compressive force varies according to the used cylinder between $1000 \mathrm{kN}$ and $630 \mathrm{kN}$ at $600 \mathrm{~mm}$ cylinder travel. The maximum piston-speed equals $4.5 \mathrm{~m} / \mathrm{s}$ and $8.5 \mathrm{~m} / \mathrm{s}$, respectively. The facility can be operated travel- or force-dependent. A forcetime- or travel-time-curve can be programmed. The dimensions are $8 \mathrm{~m} \mathrm{x} 3 \mathrm{~m} \mathrm{x}$ $2.6 \mathrm{~m}$. For the experiments here the maximum available impact speed was $3.0 \mathrm{~m} / \mathrm{s}$, resulting in an initial strain rate of $301 / \mathrm{s}$.

During the experiments hydraulic system pressure as well as force acting on the sample through a load cell situated below the wood sample (grey-red in lower right corner of Fig 7) were measured. Additionally system piston travel was measured by a magnetic induced system. Signals were recorded using a portable data logging device.

\section{Realisation of lateral strain restriction}

Steel sheets surrounding the wood sample were applied as lateral strain restriction (Fig 8). The steel sheets had $1 \mathrm{~mm}$ thickness. Tests were also performed with empty steel sheets in order to show that energy absorption by the steel housing is negligible compared to the energy absorbed by wood.

\section{Performance of tests}

The tests were performed inside a test building at ambient temperatures between $17-19^{\circ} \mathrm{C}$. The samples were photographed and then inserted into the test facility. After compression they were removed, photographed and documented. The signals were stored and later on processed.

\section{Test plan}

Table 1 shows a plan of the performed tests. Ten samples per parameter set were compressed in order to ensure statistical evaluation. Tested were axial grain 
Ejwwp442_source

direction at three different impact speeds and the whole set once with lateral strain restriction and once without any lateral strain restriction except for friction from load inducing surfaces, which were very finely machined. The three impact speeds $(0.001 \mathrm{~m} / \mathrm{s}, 0.3 \mathrm{~m} / \mathrm{s}, 3.0 \mathrm{~m} / \mathrm{s})$ result in initial strain rates of about $0.01 \mathrm{~s}^{-1}, 3 \mathrm{~s}^{-1}$ and $30 \mathrm{~s}^{-1}$.

Signal processing and statistical evaluation

The signals were processed after the tests in order to ensure comparability. Average curves for every parameter set were calculated. The statistical evaluation was performed using the Sigmaplot-Software (Sigmaplot 2007). With help of paired t-tests for unconnected entities (Rice, 2006) the statistical relevance of the differences resulting from different test conditions was assessed. Results were regarded as statistically relevant when their difference was distinct with a level of significance of $p<\alpha$ with $\alpha=0.05$. Paired t-tests require a Gaussian normal distribution, which is approximately given for mechanical properties of wood as compression strength according to Dinwoodie (2000) and Kazumi et al. (1999). The sometimes proposed Weibull distribution (Kufner 1985) is preferred for predicting the lower end of the distribution due to its weakest-link concept (Dinwoodie, 2000) and therefore, here less suitable.

\section{Results and Discussion}

\section{Resulting stress-strain curves}

Fig 9 presents average stress strain curves for samples with lateral strain restriction (left) and without (right). Since the cross section is $0.01 \mathrm{~m}^{2}$ and sample height is $0.1 \mathrm{~m}$, the earlier force deformation relationships can be obtained by multiplying abscissa values with $0.1 \mathrm{~m}$ and ordinate values with $0.01 \mathrm{~m}^{2}$. The often described lock up or densification at high levels of strain (Gibson and Ashby 1997) has not been reached in the test, strain levels remain to small. However, the beginning of densification is clearly visible in Fig 9. 
Ejwwp442_source

\section{Compression strength}

Fig 10 shows box plots of the distribution of compression strength under different strain rates and lateral strain restrictions. Table 2 states the significance levels for different strain rates and the lateral strain restriction.

The compression strength increased for samples with lateral strain restrictions with higher strain rates from $0.01 \mathrm{~s}^{-1}(53 \mathrm{MPa})$ over $3 \mathrm{~s}^{-1}(62 \mathrm{MPa})$ to $30 \mathrm{~s}^{-1}$ (69 MPa). This corresponds to impact speeds of $0.001 \mathrm{~m} / \mathrm{s}, 0.3 \mathrm{~m} / \mathrm{s}$ and $3.0 \mathrm{~m} / \mathrm{s}$. The increase of compression strength for samples without lateral strain restriction was comparable to samples with restriction (50 $\mathrm{MPa}, 62 \mathrm{MPa}, 71 \mathrm{MPa})$. The influence of strain rate was statistically relevant for all impact speeds and lateral strain restrictions (Table 2). The lateral strain restriction did not have a significant influence on the compression strength at any impact speed.

Dependency of compression strength on the lateral strain restriction was not expected since Poisson factors in elastic compression are negligible for a-r (axialradial) and a-t (axial-tangential) direction (Foster 1992) and therefore no large lateral dilatations occur. However, absence of an increase in compression strength proofs that the strain energy of the metal sheet is negligible compared to the influence of strain rate and lateral strain restriction. If the steel sheet led to a significantly increased load the influence would have to be significant here. Therefore, it can be concluded that lateral strain restriction did not affect the compression strength significantly.

\section{Stress at strain level of $\mathbf{5 0 \%}$}

Fig. 11 shows box plots of stresses at strain levels of 50\% under different strain rates and lateral strain restrictions. Table 3 states the significance levels for the influence of different strain rates and lateral strain restriction.

The stress at strain level of $50 \%$ increased with strain rate for samples with lateral strain restriction from static $(30 \mathrm{MPa})$ to $3 \mathrm{~s}^{-1}(38 \mathrm{MPa})$, results were not significant for $3-30 \mathrm{~s}^{-1}(40 \mathrm{MPa}$, compare Table 3$)$. The difference in strain rate $\left(3 s^{-1}-30 s^{-1}\right)$ might not be large enough to produce a result; more tests should be performed in order to clarify the result. The lateral strain restriction had significant influence on stress at a strain level of $50 \%$. The average stress in static mode with lateral strain restriction was about $29.6 \mathrm{MPa}$, without lateral strain restriction about 13.3 MPa. This resulted in ca. 2.2 times higher stress levels for 
Ejwwp442_source

samples with lateral strain restriction than without, for the boundary conditions in these tests.

Samples without lateral strain restriction flew partly out of the test facility during the compression process with speeds of $0.3 \mathrm{~m} / \mathrm{s}$ and $3.0 \mathrm{~m} / \mathrm{s}$. The faster the test velocity, the more fibres left the impact pad and were no more available for energy absorption. Therefore, results without lateral strain restriction at impact

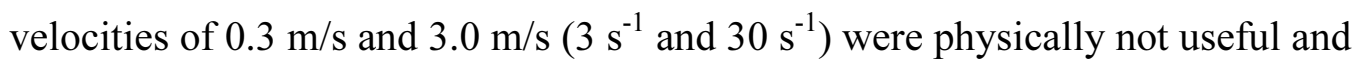
disregarded here.

For two to three samples at each impact speed lateral strain restriction failed during the compression process (Fig. 12). Results from these tests were not taken into account for the statistical evaluation of stress and energy absorption at strain level of $50 \%$.

\section{Specific energy absorption at $\mathbf{5 0} \%$ deformation}

Box plots of the strain energy levels at 50\% deformation under different strain rates and lateral strain restrictions are shown in Fig. 13. Table 4 states the significance levels for different strain rates and the lateral strain restriction. The absorbed strain energy at 50\% deformation increased with strain rate for samples with lateral strain restriction from static $\left(15.3 \mathrm{MJ} / \mathrm{m}^{3}\right)$ to $0.3 \mathrm{~m} / \mathrm{s}$ $\left(18.9 \mathrm{MJ} / \mathrm{m}^{3}\right)$. However, results were not significant for $3 \mathrm{~s}^{-1}-30 \mathrm{~s}^{-1}$ (Table 4). The resulting strain rates might not have been unequal enough; more tests should be performed in order to clarify the result. The lateral strain restriction had significant influence on absorbed strain energy at 50\% deformation. The average absorbed strain energy in static mode with lateral strain restriction was about 15.3 MJ/m³, without lateral strain restriction about $11.9 \mathrm{MJ} / \mathrm{m}^{3}$. This resulted in approximately $30 \%$ higher specific energy absorption for samples with lateral strain restriction than without, for the boundary conditions in these tests. The decrease of energy absorption with higher strain rates for samples without lateral strain restriction can be explained according to 3.3.

\section{Summary of results}

Mean values and standard deviations of compressive strength, stress at a strain level of 50\% and absorbed specific energy (strain energy) are shown in Tables 5 7. 
Ejwwp442_source

\section{Conclusion}

The influence of strain rate on the compression strength of spruce wood was quantified and proofed to be statistically significant. Compared to static tests ain the scope of packages for radioactive materials interesting - strain rate of $30 \mathrm{~s}^{-1}$ led to approximately $30 \%$ larger compression strength. The influence of strain rate between static and $30 \mathrm{~s}^{-1}$ on specific energy absorption and stress at strain level of $50 \%$ was significant, a larger strain rate led to larger energy absorption. The increase in stress at a strain level of $50 \%$ was about $36 \%$; the increase of absorbed energy was $23 \%$.

Compression strength was not dependent on lateral strain restriction. Stresses at a strain level of $50 \%$ were significantly affected by lateral strain restriction. With lateral strain restriction, consisting here of a $1 \mathrm{~mm}$ steel sheet lateral encapsulation, the stress at a strain level of $50 \%$ was by a factor of 2.2 higher than without lateral strain restriction. Absorbed specific energy at 50\% deformation (strain energy) was increased by $30 \%$ for samples with lateral strain restriction of $1 \mathrm{~mm}$ steel sheets.

Therefore, it can be concluded that for axially loaded wood under large deformations a generally valid yield curve can not be defined. The dependency of stress and therewith energy absorption capacity on lateral strain restriction leads to a set of yield curves. The choice of yield curve is then dependent on the lateral strain restriction. 
Ejwwp442_source

This work was co-sponsored by German Federal Ministry for Education and Research under contract 02S8274. The authors thank Gesellschaft für Nuklear-Service mbH (GNS) and Mitsubishi Heavy Industries (MHI) for the permission to publish pictures of their drop test objects taken at the BAM drop test facility. 
Ejwwp442_source

Adalian C, Morlier P (2002) Wood model for the dynamic behavior of wood in multiaxial compression. Holz Roh- Werkst 60, 433-439.

BAM, 2009. BAM Impact testing machine.

http://www.bam.de/en/service/publikationen/publikationen_medien/unikale pruef/upe 711_en_72.pdf

Bariska M, Kucera LJ (1985) On the fracture morphology in wood. Part2: Macroscopical deformations upon ultimate axial compression in wood. Wood Sci. Technol. 19, 19-34.

Bodig, J (1966) Stress-strain relationship for wood in transverse compression. Journal of Materials 1(3), 645-666.

Bodig J, Jayne AJ (1982) Mechanics of wood and wood composites. van Nostrand Reimhold, New York.

Daudeville L (1999) Fracture in spruce: experiment and numerical analysis by linear and non linear fracture mechanics. Holz Roh- Werkst 57, 425-432.

Debaise GR, Porter AW, Pentoney RE (1966) Morphological and mechanics of wood fracture. Materials Research and Standards 6(10), 493-499.

Dill-Langer G, Cruz Hidalgo R, Kun F, Moreno Y, Aicher S, Herrmann H J (2003) Size dependency of tension strength in natural fiber composites. Physica A 325, 547-560.

DIN EN 338, 2008. Bauholz für tragende Zwecke - Festigkeitsklassen. Deutsches Institut für Normung e.V., Berlin.

DIN 4074, 2008. Sortierung von Holz nach der Tragfähigkeit. Deutsches Institut für Normung e.V., Berlin.

DIN 52185, 1976. Prüfung von Holz - Bestimmung der Druckfestigkeit parallel zur Faser. Fachnormenausschuss Materialprüfung im Deutschen Institut für Normung e.V., Berlin. Dinwoodie JM (2000) Timber: its nature and behaviour. 2nd edition, E and FN Spon, London. Easterling KE, Harrysson R, Gibson LJ, Ashby MF (1982) On the mechanics of balsa and other woods. Proceedings of Royal Society A 383, 31-41.

Eberhardsteiner J (2002) Mechanisches Verhalten von Fichtenholz, Experimentelle Bestimmung der biaxialen Festigkeitseigenschaften. Springer, Wien.

Fengel D, Wegener G (1989) Wood - Cemistry, Ultrastructure, Reactions. De Gruyter, Berlin. Forest Products Laboratory, 1999. Wood Handbook - Wood as an engineering material. Gen. Tech. Rep. FPL-GTR-113. Madison, WI, USA.

Foster CG (1992) Damping and poisson factor behavior in timber considered as an orthotropic material, part 1, the loss factor. Journal of Sound and Vibration 158(3), 405-425.

Gibson LJ, Ashby MF (1997) Cellular solids. 2nd edition, Cambridge University Press, Cambridge.

Gindl W (2002) Comparing mechanical properties of normal and compression wood in Norway spruce: The role of lignin in compression parallel to grain. Holzforschung 56, 395-401.

Gong M, Smith I (2000) Failure of softwood under static compression parallel to grain, Journal of the Institute of Wood Science 15(4), 204-210.

Grimsel M (1999) Mechanisches Verhalten von Holz, Dresden: Techn. Univ., Diss. 
Ejwwp442_source

Grosse M (2005) Zur numerischen Simulation des physikalisch nichtlinearen

Kurzzeittragverhaltens von Nadelholz am Beispiel von Holz-Beton- Verbundkonstruktionen.

Doctoral Thesis, Bauhaus University, Weimar.

Hamdan, S., Dwianto W, Morooka T, Norimoto M (2000) Softening characteristics of wet wood under quasi static loading. Holzforschung 54, 557-560

Hermanson JC (1996) The triaxial behaviour of redwood using a new confined compression device, PhD-thesis, Graduate School of the University of Wisconsin.

IAEA (2005) Safety Guide TS-R-1. Regulations for the Safe Transport of Radioactive Material, IAEA, Vienna.

IAEA (2008) Safety Guide TS-G-1.1. Advisory Material for the IAEA Regulations for the Safe Transport of Radioactive Material, IAEA, Vienna.

Kazumi H, Noboru N, Yasuo,I (1999) Analysis of the Strength Data of wood Structures on Limit States Design. I. The influence of probabilistic and statistic method on specified values. Journal of the Japan Wood Research Society, 45(2), 103-110.

Keith CT (1972) The mechanical behaviour of wood in longitudinal compression. Wood Science, 4(4), 234-244.

Kollmann F (1936) Technologie des Holzes und der Holzwerkstoffe. Springer, Berlin.

Kollmann F (1982) Technologie des Holzes und der Holzwerkstoffe. Springer, Berlin.

Kufner M (1985) Distribution of wood property values within a Norway spruce log. Holz RohWerkst 43(4), 123-129.

Mascia NT,Cramer SM (2000) Effect of moisture content, specific gravity, temperature and number of annual growth rings on redwood elastic constants, World Conference on Timber Engineering Whistler Resort, British Columbia, Canada July 31 - August 3, 2000.

Mackenzie-Helnwein P, Eberhardsteiner J, Mang, HA (2003) A multisurface plasticity model for clear wood and its application to the finite element analysis of structural details. Computational Mechanics 31, 204-218.

Müller U (2003) Effects of wood macro- and micro-structure on selected mechanical properties.

Doctoral thesis, University of Natural Resources and Applied Life Sciences, Vienna.

Musolff A, Müller K, Neumann M, Kadji A, Droste B (2008) Results of full scale CONSTOR V/TC prototype 9m horizontal drop test. PTSSRAM 19(4), 228-232.

Niemz P (1993) Physik des Holzes und der Holzwerkstoffe. DRW-Verlag Weinbrenner GmbH \& Co., Leinfelden Echterdingen.

Poulsen JS (1997) Compression in clear wood. Dissertation, University Lyngby.

Reid SR, Peng C (1997) Dynamic uniaxial crushing of wood. International Journal of Impact Engineering 19(5-6), 531-570.

Quercetti T, Mueller K, Schubert S (2007) Comparison of experimental results from drop testing of a spent fuel package design using a full scale prototype model and a reduced scale model. In Proceedings of PATRAM 2007, October 21.-26., Miami, USA.

Reiterer A, Stanzl-Tschegg SE (2001) Compressive behaviour of softwood under uniaxial loading at different orientations to the grain. Mechanics of Materials 33, 705-715.

Rice JA (2006) Mathematical Statistics and Data Analysis. Duxbury Press, 3rd edition, Belmont. 


\section{Ejwwp442_source}

Schneeweiss, G., 1963. Der Groesseneinfluss im Druckversuch quer zur Faser. Holzforsch. Holzverwert. 15, 125-130.

Seborg RM, Stamm AJ (1941) The compression of wood. Mechanical Engineering March 1941, 211-213.

Sigmaplot 10, Scientific Solutions SA, Pully-Lausanne, Switzerland, 2007.

Smith I, Vasic S (2003) Fracture behavior of softwood. Mechanics of Materials 35, 803-815.

Tabarsa T, Chui YH (2001) Stress strain response of wood under radial compression. Part I. Test method and influences of cellular properties. Wood Fiber Sci 33(2), 223-232.

Vural M, Ravichandran G (2003) Dynamic response and energy dissipation characteristics of balsa wood: experiment and analysis. International Journal of Solids and Structures 40, 2147-2170. 


\section{Ejwwp442_source}

\section{Figures English}

Fig 1 Stress-strain relationship for axially loaded balsa-wood from Gibson and Ashby (1997)

Fig 2 Cask with attached impact limiters (white) at both ends after $9 \mathrm{~m}$ horizontal drop test, including schematic sketch of left-end impact limiter cross section with zones of different energy absorption (A, B)

Fig 3 Piece of spruce wood from deformed impact limiter; beginning of buckling after lateral tensile failure

Fig 4 Impact limiter zone of mainly axial wood compression and large energy absorption (comparable to zone B in Fig 2)

Fig 5 Impact limiter zone with deformation of laterally little restricted pieces of wood (comparable to zone A in Fig 2)

Fig 6 Cube-shaped sample of spruce wood in dimensions of $100 \mathrm{~mm}$ x $100 \mathrm{~mm} \times 100 \mathrm{~mm}$

Fig 7 BAM $1000 \mathrm{kN}$ impact test facility

Fig 8 Lateral strain restriction of axially loaded wood by partial (lateral) encapsulation with $1 \mathrm{~mm}$ welded steel sheets before (left) and after (right) compression test

Fig 9 Average stress strain curves of axially loaded spruce wood for different impact speeds $(0.001$ $\mathrm{m} / \mathrm{s}, 0.3 \mathrm{~m} / \mathrm{s}, 3.0 \mathrm{~m} / \mathrm{s}$, initial strain rates $0.01 \mathrm{~s}^{-1}, 3.0 \mathrm{~s}^{-1}$ and $30 \mathrm{~s}^{-1}$ ) for sample cross sections of $0.01 \mathrm{~m}^{2}$ and sample heights of $0.1 \mathrm{~m}$; left: with lateral strain restriction ( $1 \mathrm{~mm}$ steel sheet); right: without lateral strain restriction

Fig 10 Box plots of compressive strength of axially loaded spruce wood for three different impact speeds $\left(0.001 \mathrm{~m} / \mathrm{s}, 0.3 \mathrm{~m} / \mathrm{s}, 3.0 \mathrm{~m} / \mathrm{s}\right.$, initial strain rates $0.01 \mathrm{~s}^{-1}, 3.0 \mathrm{~s}^{-1}$ and $\left.30 \mathrm{~s}^{-1}\right)$ for samples with lateral strain restriction $1 \mathrm{~mm}$ steel sheet $(\mathrm{ml})$ and samples without lateral strain restriction (ol) for sample cross sections of $0.01 \mathrm{~m}^{2}$ and sample heights of $0.1 \mathrm{~m}$

Fig 11 Box plots of stress at a strain level of 50\% of axially loaded spruce wood for three different impact speeds $\left(0.001 \mathrm{~m} / \mathrm{s}, 0.3 \mathrm{~m} / \mathrm{s}, 3.0 \mathrm{~m} / \mathrm{s}\right.$, initial strain rates $0.01 \mathrm{~s}^{-1}, 3.0 \mathrm{~s}^{-1}$ and $\left.30 \mathrm{~s}^{-1}\right)$ for samples with lateral strain restriction $1 \mathrm{~mm}$ steel sheet $(\mathrm{ml})$ and samples without lateral strain restriction (ol) for sample cross sections of $0.01 \mathrm{~m}^{2}$ and sample heights of $0.1 \mathrm{~m}$.

Fig 12 Failed lateral strain restriction

Fig 13 Box plots of strain energy at 50\% deformation of axially loaded spruce wood for three different impact speeds $\left(0.001 \mathrm{~m} / \mathrm{s}, 0.3 \mathrm{~m} / \mathrm{s}, 3.0 \mathrm{~m} / \mathrm{s}\right.$, initial strain rates $0.01 \mathrm{~s}^{-1}, 3.0 \mathrm{~s}^{-1}$ and $\left.30 \mathrm{~s}^{-1}\right)$ for samples with lateral strain restriction $1 \mathrm{~mm}$ steel sheet $(\mathrm{ml})$ and samples without lateral strain restriction (ol) for sample cross sections of $0.01 \mathrm{~m}^{2}$ and sample heights of $0.1 \mathrm{~m}$. 
Ejwwp442_source

\section{Abb deutsch}

Abb, 1 Spannungs-Dehnungs-Zusammenhang für axial beanspruchtes Balsaholz nach Gibson und Ashby (1997)

Abb, 2 Behälter mit befestigten stoßdämpfenden Bauteilen an beiden Enden nach einem 9m Horizontalfallversuch inklusive einer Skizze des Querschnitts des linken Stoßdämpfers mit verschiedenen Energieabsorptionszonen

Abb, 3 Fichtenholzstück aus verformten Stoßdämpfer, beginnendes Ausknicken nach Lateralzugversagen

Abb, 4 Stoßdämpferbereich mit hauptsächlich axialer Holzkomprimierung und großer Energieabsorption (vergleichbar mit Zone B in Abb. 2)

Abb, 5 Stoßdämpferbereich mit Holzkomprimierung unter geringer seitlicher Dehnungsbehinderung (vergleichbar mit Zone A in Abb. 2)

Abb, 6 Würfelförmige Fichtenholzprobe mit den Abmessungen 100 mm x 100 mm x 100 mm Abb, 7 BAM 1000 kN Stoßprüfstand

Abb, 8 Partielle seitliche Dehnungsbehinderung mit $1 \mathrm{~mm}$ starkem verschweißtem Stahlblech vor (links) und nach (rechts) dem Versuch

Abb, 9 Mittlere Spannungs-Dehnungs-Verläufe von axial beanspruchtem Fichtenholz für verschiedene Beanspruchungsgeschwindigkeiten $(0.001 \mathrm{~m} / \mathrm{s}, 0.3 \mathrm{~m} / \mathrm{s}, 3.0 \mathrm{~m} / \mathrm{s}$, entspricht initialer Dehnrate von $0.01 \mathrm{~s}^{-1}, 3.0 \mathrm{~s}^{-1}$ and $30 \mathrm{~s}^{-1}$ ) für eine Probenquerschnittsfläche von $0.01 \mathrm{~m}^{2}$ und einer Probenhöhe von 0.1m; links: mit lateraler Dehnungsbehinderung (1mm Stahlblech); rechts: ohne seitliche Dehnungsbehinderung

Abb, 10 Box Plots der Druckfestigkeit von axial beanspruchtem Fichtenholz für verschiedene Beanspruchungsgeschwindigkeiten $(0.001 \mathrm{~m} / \mathrm{s}, 0.3 \mathrm{~m} / \mathrm{s}, 3.0 \mathrm{~m} / \mathrm{s}$, entspricht initialer Dehnrate von $0.01 \mathrm{~s}^{-1}, 3.0 \mathrm{~s}^{-1}$ und $30 \mathrm{~s}^{-1}$ ) für Proben mit seitlicher Dehnungsbehinderung (ml) und Proben ohne seitliche Dehnungsbehinderung (ol) für eine Probenquerschnittsfläche von $0.01 \mathrm{~m}^{2}$ und einer Probenhöhe von $0.1 \mathrm{~m}$

Abb, 11 Box Plots der Druckspannung bei 50\% Stauchung von axial beanspruchtem Fichtenholz für verschiedene Beanspruchungsgeschwindigkeiten $(0.001 \mathrm{~m} / \mathrm{s}, 0.3 \mathrm{~m} / \mathrm{s}, 3.0 \mathrm{~m} / \mathrm{s}$, entspricht initialer Dehnrate von $0.01 \mathrm{~s}^{-1}, 3.0 \mathrm{~s}^{-1}$ und $30 \mathrm{~s}^{-1}$ ) für Proben mit seitlicher Dehnungsbehinderung (ml) und Proben ohne seitliche Dehnungsbehinderung (ol) für eine Probenquerschnittsfläche von $0.01 \mathrm{~m}^{2}$ und einer Probenhöhe von $0.1 \mathrm{~m}$

Abb. 12 Probe, bei der seitliche Dehnungsbehinderung versagt hat

Abb. 13 Box Plots der Verformungsenergien bei 50\% Stauchung von axial beanspruchtem

Fichtenholz für verschiedene Beanspruchungsgeschwindigkeiten $(0.001 \mathrm{~m} / \mathrm{s}, 0.3 \mathrm{~m} / \mathrm{s}, 3.0 \mathrm{~m} / \mathrm{s}$, entspricht initialer Dehnrate von $0.01 \mathrm{~s}^{-1}, 3.0 \mathrm{~s}^{-1}$ und $30 \mathrm{~s}^{-1}$ ) für Proben mit seitlicher Dehnungsbehinderung ( $\mathrm{ml}$ ) und Proben ohne seitliche Dehnungsbehinderung (ol) für eine Probenquerschnittsfläche von $0.01 \mathrm{~m}^{2}$ und einer Probenhöhe von $0.1 \mathrm{~m}$ 


\section{Ejwwp442_source}

Table 1 Test plan for impact tests on spruce wood, sample dimensions $0.1 \mathrm{~m}$ x $0.1 \mathrm{~m}$ x0.1 m

Tab 1 Versuchsplan für Stoßversuche auf Fichtenholz, Probeabmessungen $0.1 \mathrm{~m}$ x $0.1 \mathrm{~m}$ x0.1 m

\begin{tabular}{|l|l|l|l|}
\hline Test set & Number & Impact speed & Lateral strain restriction \\
\hline $\mathrm{ml1}$ & 10 & $0.001 \mathrm{~m} / \mathrm{s}$ & $1 \mathrm{~mm}$ steel sheet \\
\hline $\mathrm{ml} 300$ & 10 & $0.3 \mathrm{~m} / \mathrm{s}$ & $1 \mathrm{~mm}$ steel sheet \\
\hline $\mathrm{ml} 3000$ & 10 & $3.0 \mathrm{~m} / \mathrm{s}$ & $1 \mathrm{~mm}$ steel sheet \\
\hline ol1 & 10 & $0.001 \mathrm{~m} / \mathrm{s}$ & none \\
\hline ol300 & 10 & $0.3 \mathrm{~m} / \mathrm{s}$ & none \\
\hline ol3000 & 10 & $3.0 \mathrm{~m} / \mathrm{s}$ & none \\
\hline
\end{tabular}

Table 2 Significance levels $(\mathrm{p})$ for influence of three different impact speeds $(0.001 \mathrm{~m} / \mathrm{s}, 0.3 \mathrm{~m} / \mathrm{s}$, $3.0 \mathrm{~m} / \mathrm{s}$, initial strain rates $0.01 \mathrm{~s}^{-1} 3.0 \mathrm{~s}^{-1}$ and $30 \mathrm{~s}^{-1}$ ) and strain restriction on compression strength for samples with lateral strain restriction $1 \mathrm{~mm}$ steel sheet $(\mathrm{ml})$ and samples without lateral strain restriction (ol) for sample cross sections of $0.01 \mathrm{~m}^{2}$ and sample heights of $0.1 \mathrm{~m}$ on compressive strength

Tab 2 Signifikanzniveaus (p) des Einflusses dreier Beanspruchungsgeschwindigkeiten $(0.001 \mathrm{~m} / \mathrm{s}$, $0.3 \mathrm{~m} / \mathrm{s}, 3.0 \mathrm{~m} / \mathrm{s}$, entspricht initialer Dehnrate von $0.01 \mathrm{~s}^{-1}, 3.0 \mathrm{~s}^{-1}$ und $30 \mathrm{~s}^{-1}$ ) auf die Druckfestigkeit für Proben mit seitlicher Dehnungsbehinderung $(\mathrm{ml})$ und Proben ohne seitliche Dehnungsbehinderung (ol) für eine Probenquerschnittsfläche von $0.01 \mathrm{~m}^{2}$ und einer Probenhöhe von $0.1 \mathrm{~m}$

\begin{tabular}{|c|c|c|c|c|c|c|}
\hline & $\mathrm{mll}$ & $\mathrm{ml} 300$ & $\mathrm{ml} 3000$ & oll & ol300 & ol3000 \\
\hline $\mathrm{ml1}$ & - & $7.5 e-4$ & $1.3 \mathrm{e}-7$ & 0.104 & & \\
\hline $\mathrm{ml} 300$ & & - & $1.2 \mathrm{e}-3$ & & 0.85 & \\
\hline $\mathrm{ml} 3000$ & & & - & & & 0.25 \\
\hline ol1 & & & & - & $7.5 \mathrm{e}-7$ & $1.0 \mathrm{e}-10$ \\
\hline ol300 & & & & & - & $3.9 \mathrm{e}-4$ \\
\hline ol3000 & & & & & & - \\
\hline
\end{tabular}

Tab 3 Significance levels (p) for influence of three different impact speeds $(0.001 \mathrm{~m} / \mathrm{s}, 0.3 \mathrm{~m} / \mathrm{s}$, $3.0 \mathrm{~m} / \mathrm{s}$, initial strain rates $0.01 \mathrm{~s}^{-1}, 3.0 \mathrm{~s}^{-1}$ and $30 \mathrm{~s}^{-1}$ ) and strain restriction on stress at strain level of $50 \%$ for samples with lateral strain restriction $1 \mathrm{~mm}$ steel sheet $(\mathrm{ml})$ and samples without lateral strain restriction (ol) for sample cross sections of $0.01 \mathrm{~m}^{2}$ and sample heights of $0.1 \mathrm{~m}$ on stress at strain level of $50 \%$ 


\section{Ejwwp442_source}

Table 3 Signifikanzniveaus (p) des Einflusses dreier Beanspruchungsgeschwindigkeiten (0.001 $\mathrm{m} / \mathrm{s}, 0.3 \mathrm{~m} / \mathrm{s}, 3.0 \mathrm{~m} / \mathrm{s}$, entspricht initialer Dehnrate von $0.01 \mathrm{~s}^{-1}, 3.0 \mathrm{~s}^{-1}$ und $30 \mathrm{~s}^{-1}$ ) auf die Druckspannung bei 50\% Stauchung für Proben mit seitlicher Dehnungsbehinderung (ml) und Proben ohne seitliche Dehnungsbehinderung (ol) für eine Probenquerschnittsfläche von $0.01 \mathrm{~m}^{2}$ und einer Probenhöhe von $0.1 \mathrm{~m}$

\begin{tabular}{|l|l|l|l|l|l|l|}
\hline & $\mathrm{ml1}$ & $\mathrm{ml} 300$ & $\mathrm{ml3000}$ & ol1 & ol300 & ol3000 \\
\hline $\mathrm{ml1}$ & - & 0.0249 & $9.6 \mathrm{e}-3$ & $2.3 \mathrm{e}-4$ & & \\
\hline $\mathrm{ml300}$ & & - & 0.371 & & 0.0 & \\
\hline $\mathrm{ml} 3000$ & & & - & & & $3.3 \mathrm{e}-9$ \\
\hline ol1 & & & & - & 0.0185 & $5.1 \mathrm{e}-3$ \\
\hline ol300 & & & & & - & 0.159 \\
\hline ol3000 & & & & & & - \\
\hline
\end{tabular}

Table 4 Significance levels (p) for influence of three different impact speeds $(0.001 \mathrm{~m} / \mathrm{s}, 0.3 \mathrm{~m} / \mathrm{s}$, $3.0 \mathrm{~m} / \mathrm{s}$, initial strain rates $0.01 \mathrm{~s}^{-1}, 3.0 \mathrm{~s}^{-1}$ and $30 \mathrm{~s}^{-1}$ ) and strain restriction on strain energy at $50 \%$ deformation for samples with lateral strain restriction $1 \mathrm{~mm}$ steel sheet $(\mathrm{ml})$ and samples without lateral strain restriction (ol) for sample cross sections of $0.01 \mathrm{~m}^{2}$ and sample heights of $0.1 \mathrm{~m}$ on stress at strain level of $50 \%$

Tab 4 Signifikanzniveaus (p) des Einflusses dreier Beanspruchungsgeschwindigkeiten $(0.001 \mathrm{~m} / \mathrm{s}$, $0.3 \mathrm{~m} / \mathrm{s}, 3.0 \mathrm{~m} / \mathrm{s}$, entspricht initialer Dehnrate von $0.01 \mathrm{~s}^{-1}, 3.0 \mathrm{~s}^{-1}$ und $30 \mathrm{~s}^{-1}$ ) auf die Energieabsorption bei 50\% Stauchung für Proben mit seitlicher Dehnungsbehinderung (ml) und Proben ohne seitliche Dehnungsbehinderung (ol) für eine Probenquerschnittsfläche von $0.01 \mathrm{~m}^{2}$ und einer Probenhöhe von $0.1 \mathrm{~m}$

\begin{tabular}{|l|l|l|l|l|l|l|}
\hline & $\mathrm{ml1}$ & $\mathrm{ml300}$ & $\mathrm{ml3000}$ & oll & ol300 & ol3000 \\
\hline $\mathrm{ml1}$ & - & $1.3 \mathrm{e}-3$ & $1.3 \mathrm{e}-3$ & 0.037 & & \\
\hline $\mathrm{ml300}$ & & - & 0.90 & & $4.0 \mathrm{e}-10$ & \\
\hline $\mathrm{ml} 3000$ & & & - & & & $3.1 \mathrm{e}-7$ \\
\hline ol1 & & & & - & $8.2 \mathrm{e}-3$ & 0.0101 \\
\hline ol300 & & & & & - & 0.57 \\
\hline ol3000 & & & & & & - \\
\hline
\end{tabular}

Table 5 Mean values and standard deviations of compression strength for axially loaded spruce wood for different impact speeds $\left(0.001 \mathrm{~m} / \mathrm{s}, 0.3 \mathrm{~m} / \mathrm{s}, 3.0 \mathrm{~m} / \mathrm{s}\right.$, resulting initial strain rates $0.01 \mathrm{~s}^{-1}$, $\left.3 \mathrm{~s}^{-1}, 30 \mathrm{~s}^{-1}\right)$ for samples with (ml) and without (ol) lateral strain restriction 


\section{Ejwwp442_source}

Tab 5 Mittelwerte und Standardabweichungen der Druckfestigkeiten von axial beanspruchtem Fichtenholz für drei Beanspruchungsgeschwindigkeiten $(0.001 \mathrm{~m} / \mathrm{s}, 0.3 \mathrm{~m} / \mathrm{s}, 3.0 \mathrm{~m} / \mathrm{s}$, entspricht initialer Dehnrate von $0.01 \mathrm{~s}^{-1}, 3.0 \mathrm{~s}^{-1}$ und $30 \mathrm{~s}^{-1}$ ) für Proben mit (ml) und ohne (ol) seitliche Dehnungsbehinderung

\begin{tabular}{|l|l|l|}
\hline Test set & Mean $[\mathrm{MPa}]$ & Standard deviation [MPa] \\
\hline $\mathrm{ml1}$ & 53.0 & 5.23 \\
\hline $\mathrm{ml300}$ & 62.2 & 4.84 \\
\hline $\mathrm{ml3000}$ & 69.2 & 3.12 \\
\hline ol1 & 49.8 & 2.77 \\
\hline ol300 & 62.6 & 4.70 \\
\hline ol3000 & 71.1 & 4.08 \\
\hline
\end{tabular}

Table 6 Mean values and standard deviations of stress at a strain level of 50\% for axially loaded spruce wood for different impact speeds $(0.001 \mathrm{~m} / \mathrm{s}, 0.3 \mathrm{~m} / \mathrm{s}, 3.0 \mathrm{~m} / \mathrm{s}$, resulting initial strain rates $0.01 \mathrm{~s}^{-1}, 3 \mathrm{~s}^{-1}, 30 \mathrm{~s}^{-1}$ ) for samples with (ml) and without (ol) lateral strain restriction

Tab 6 Mittelwerte und Standardabweichungen der Spannung bei 50\% Stauchung von axial beanspruchtem Fichtenholz für drei Beanspruchungsgeschwindigkeiten $(0.001 \mathrm{~m} / \mathrm{s}, 0.3 \mathrm{~m} / \mathrm{s}, 3.0$ $\mathrm{m} / \mathrm{s}$, entspricht initialer Dehnrate von $0.01 \mathrm{~s}^{-1}, 3.0 \mathrm{~s}^{-1}$ und $30 \mathrm{~s}^{-1}$ ) für Proben mit (ml) und ohne (ol) seitliche Dehnungsbehinderung

\begin{tabular}{|l|l|l|}
\hline Test set & Mean [MPa] & Standard deviation [MPa] \\
\hline ml1 & 29.6 & 7.01 \\
\hline ml300 & 38.0 & 5.31 \\
\hline ml3000 & 40.4 & 2.22 \\
\hline ol1 & 13.3 & 6.05 \\
\hline ol300 & 7.9 & 2.54 \\
\hline ol3000 & 5.2 & 5.31 \\
\hline
\end{tabular}

Table 7 Mean values and standard deviations of specific energy (strain energy) at $50 \%$ deformation for axially loaded spruce wood for different impact speeds $(0.001 \mathrm{~m} / \mathrm{s}, 0.3 \mathrm{~m} / \mathrm{s}$, $3.0 \mathrm{~m} / \mathrm{s}$, resulting initial strain rates $0.01 \mathrm{~s}^{-1}, 3 \mathrm{~s}^{-1}, 30 \mathrm{~s}^{-1}$ ) for samples with (ml) and without (ol) lateral strain restriction

Tab 7 Mittelwerte und Standardabweichungen der Verformungsenergie bei 50\% Stauchung von axial beanspruchtem Fichtenholz für drei Beanspruchungsgeschwindigkeiten $(0.001 \mathrm{~m} / \mathrm{s}, 0.3 \mathrm{~m} / \mathrm{s}$, 


\section{Ejwwp442_source}

$3.0 \mathrm{~m} / \mathrm{s}$, entspricht initialer Dehnrate von $0.01 \mathrm{~s}^{-1}, 3.0 \mathrm{~s}^{-1}$ und $30 \mathrm{~s}^{-1}$ ) für Proben mit (ml) und ohne (ol) seitliche Dehnungsbehinderung

\begin{tabular}{|l|l|l|}
\hline Test set & Mean $\left[\mathrm{MJ} / \mathrm{m}^{3}\right]$ & Standard deviation $\left[\mathrm{MJ} / \mathrm{m}^{3}\right]$ \\
\hline $\mathrm{m} 11$ & 15.3 & 1.40 \\
\hline $\mathrm{ml300}$ & 18.9 & 1.69 \\
\hline $\mathrm{ml} 3000$ & 18.8 & 1.49 \\
\hline ol1 & 12.0 & 3.22 \\
\hline ol300 & 8.4 & 1.55 \\
\hline ol3000 & 7.0 & 2.97 \\
\hline
\end{tabular}




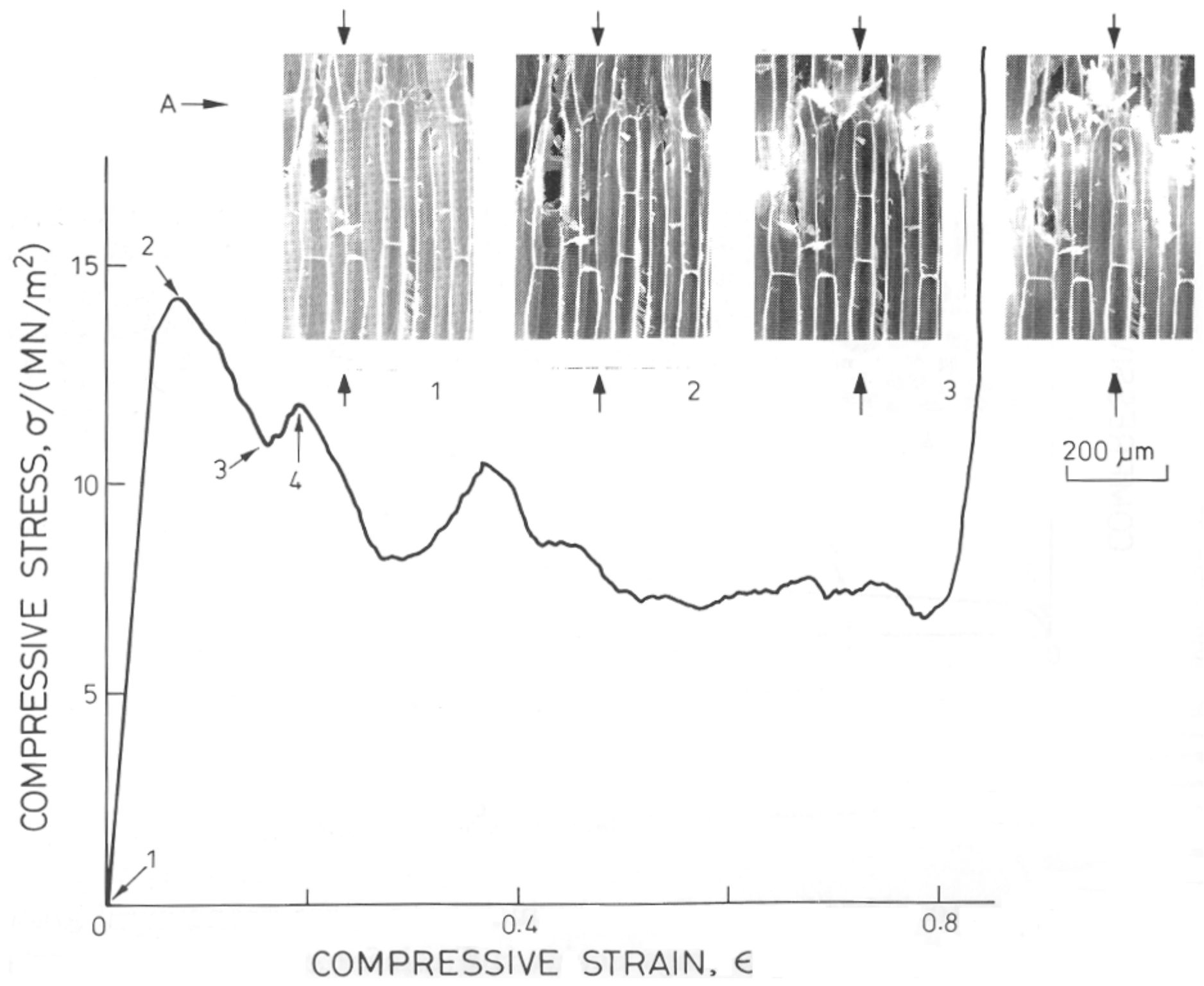




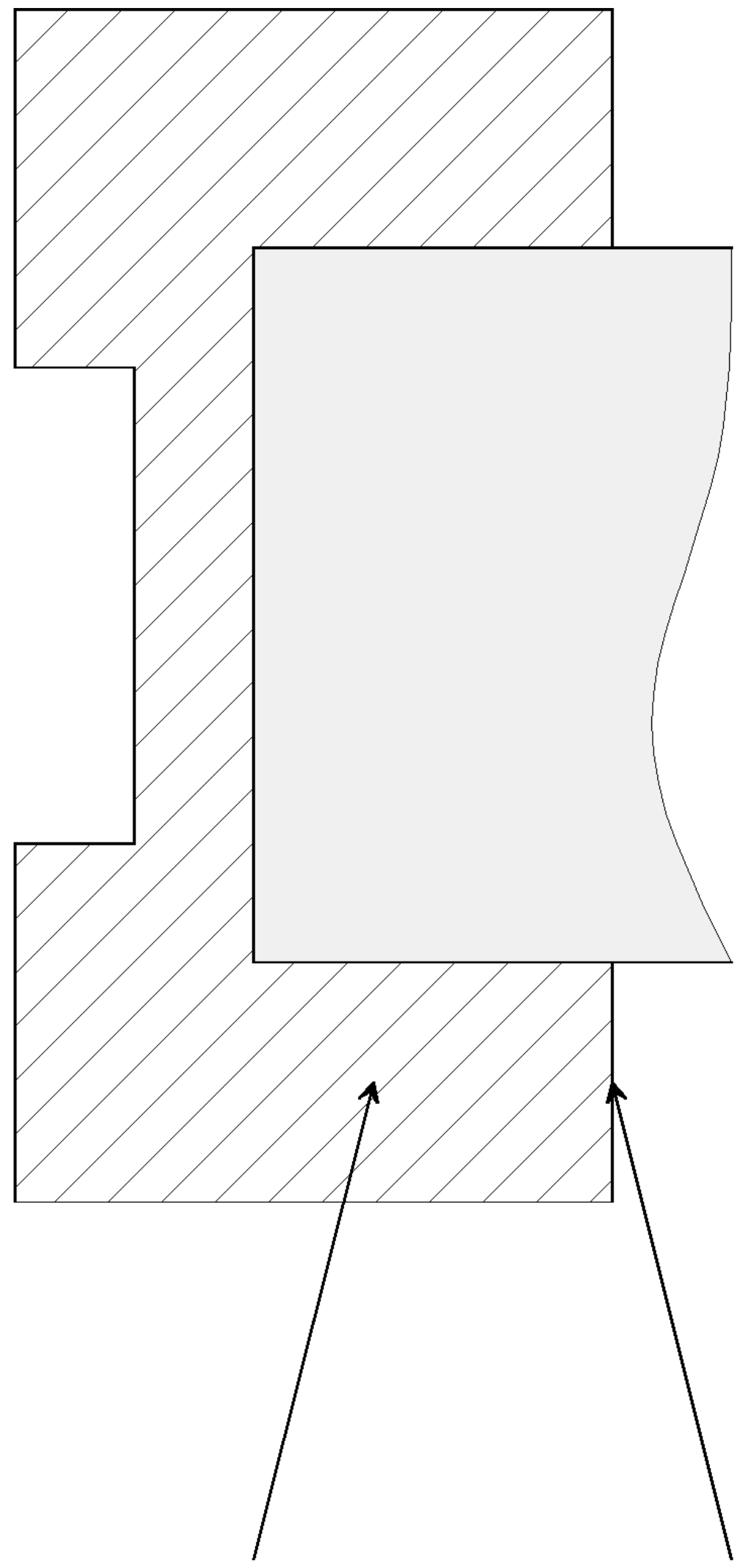

Fig 02a

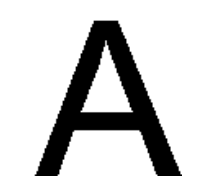




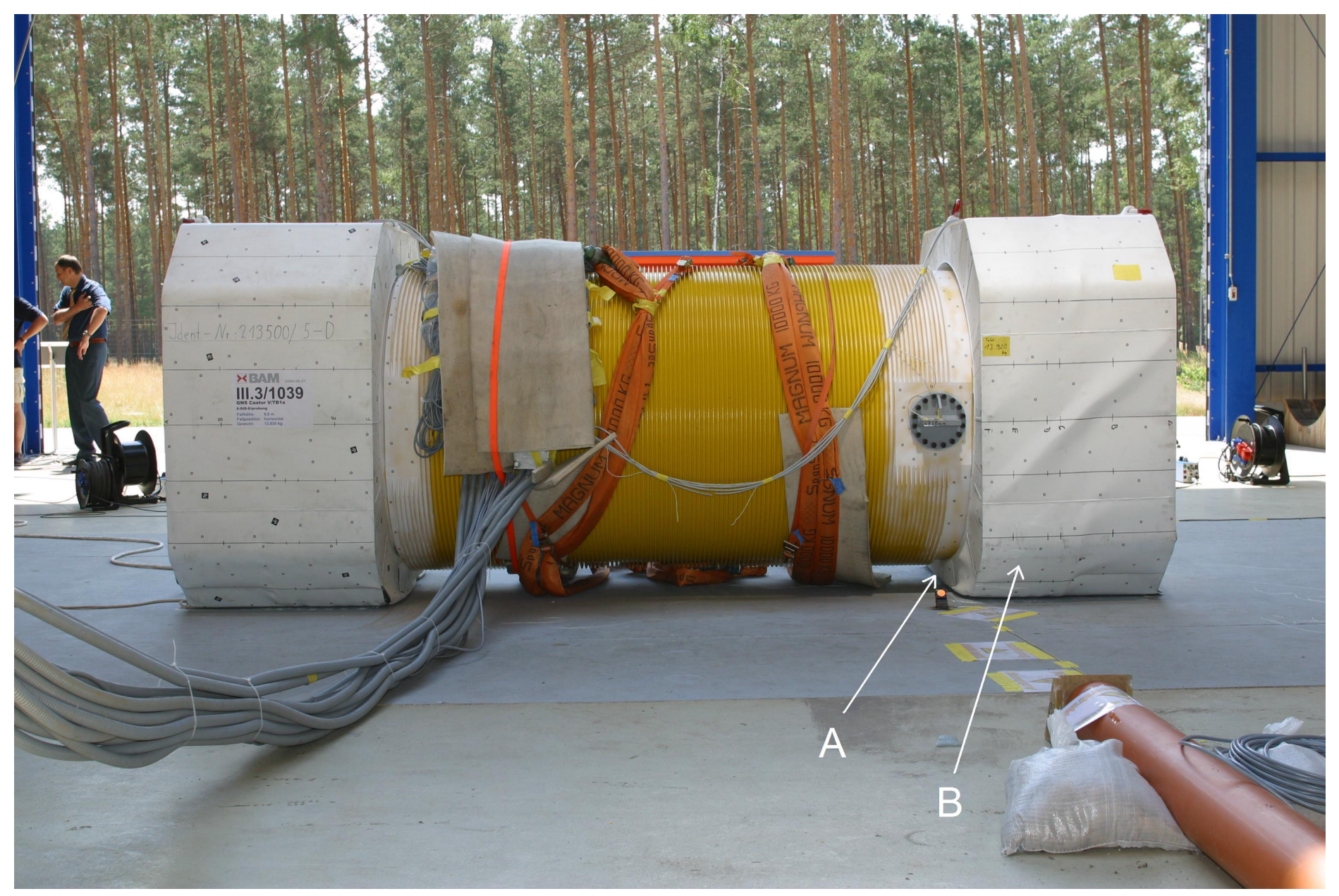

Fig 02b 


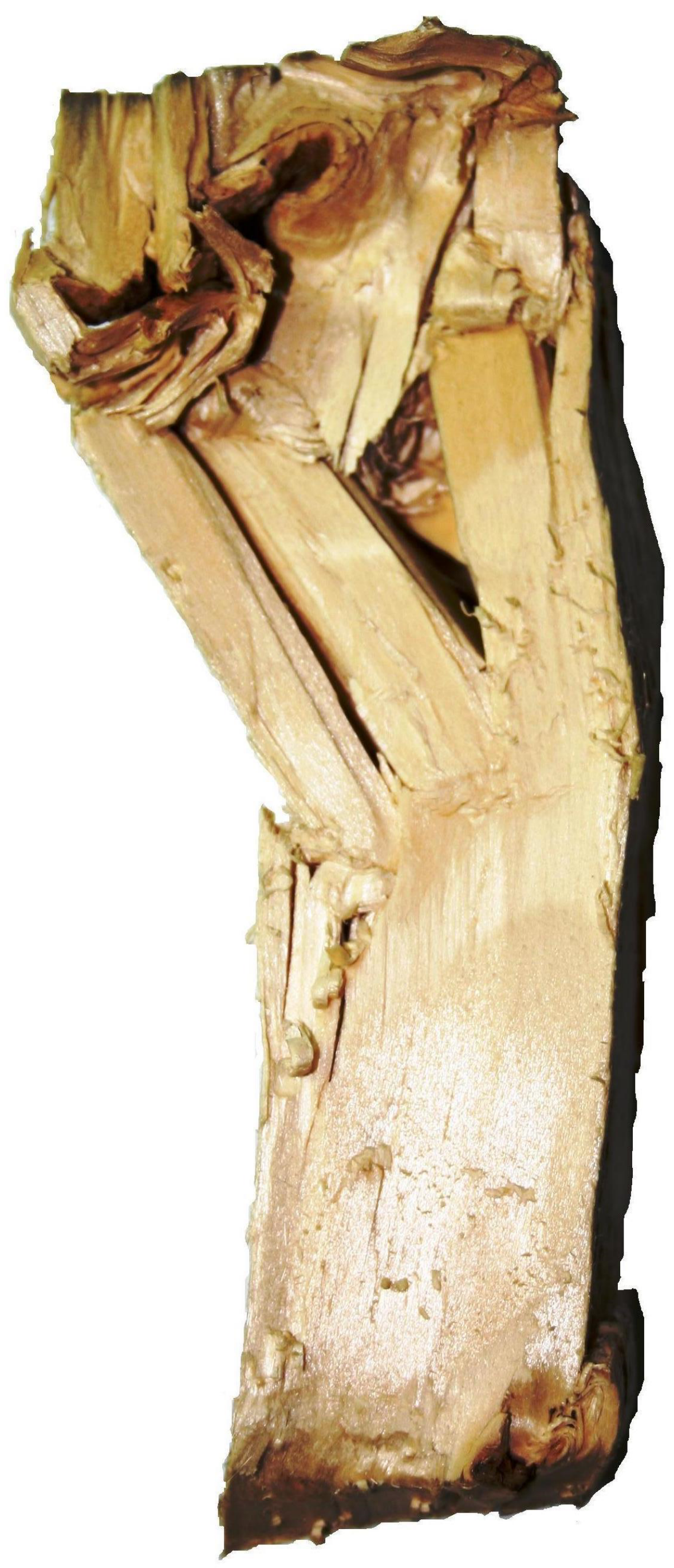

Fig 03 


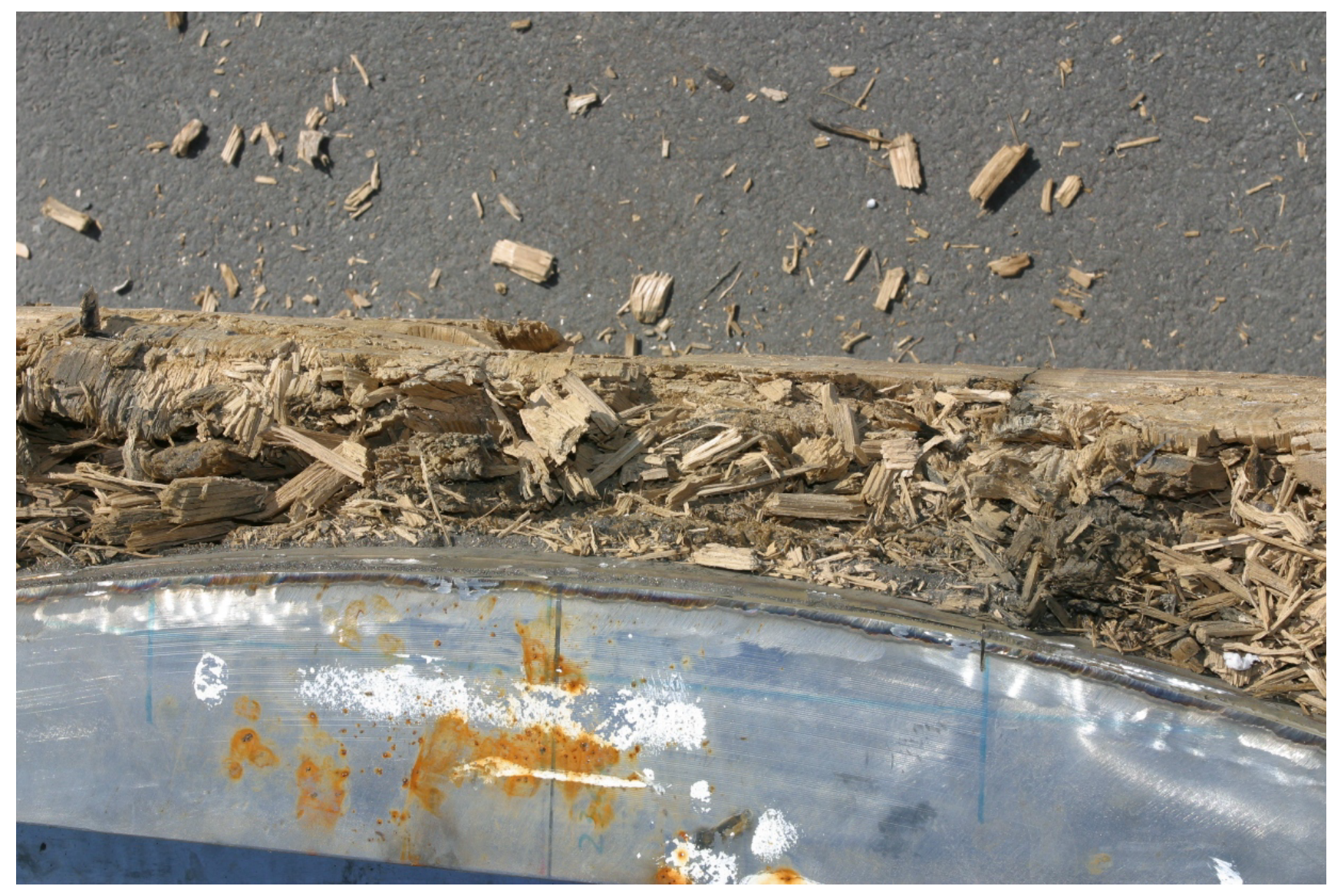




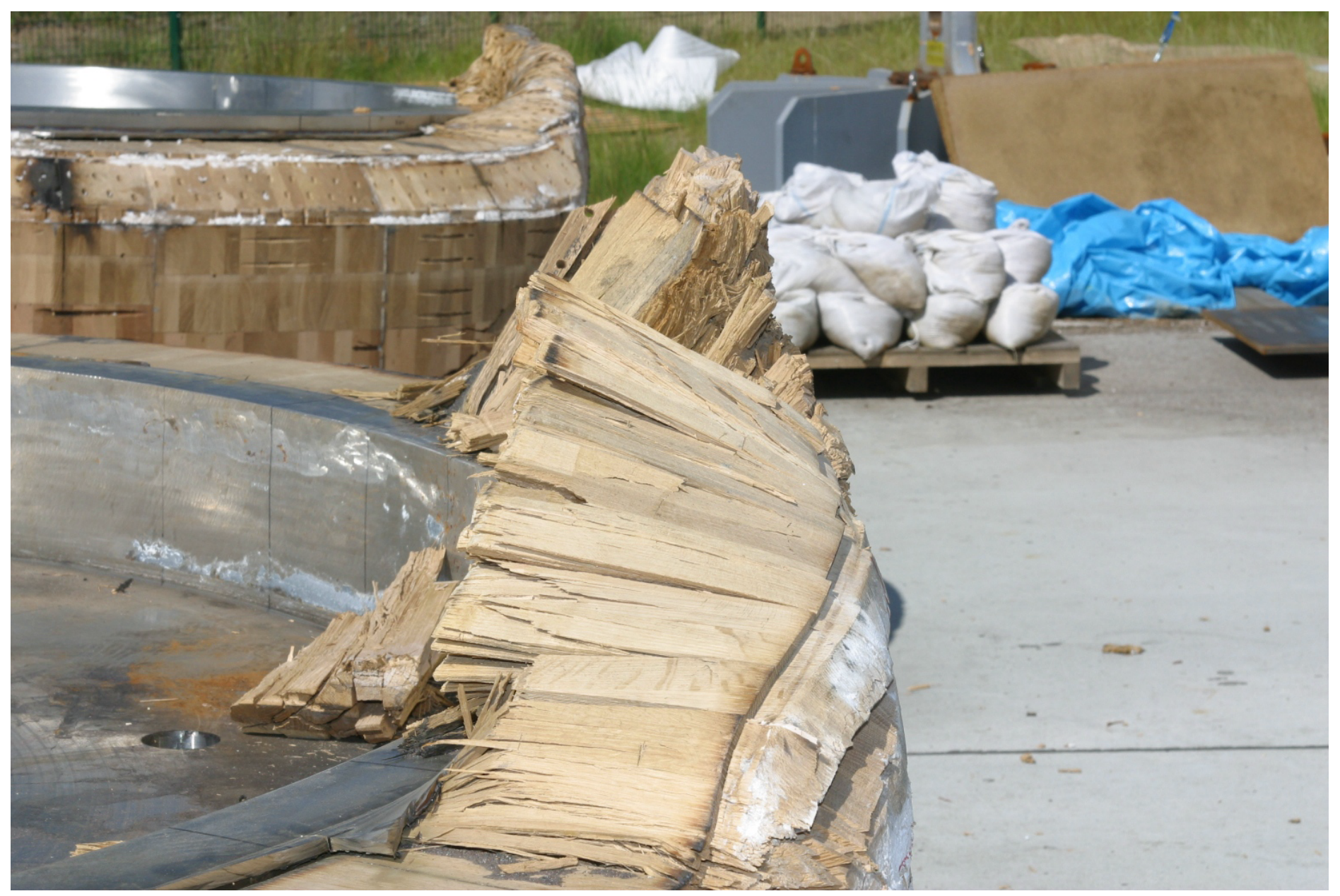




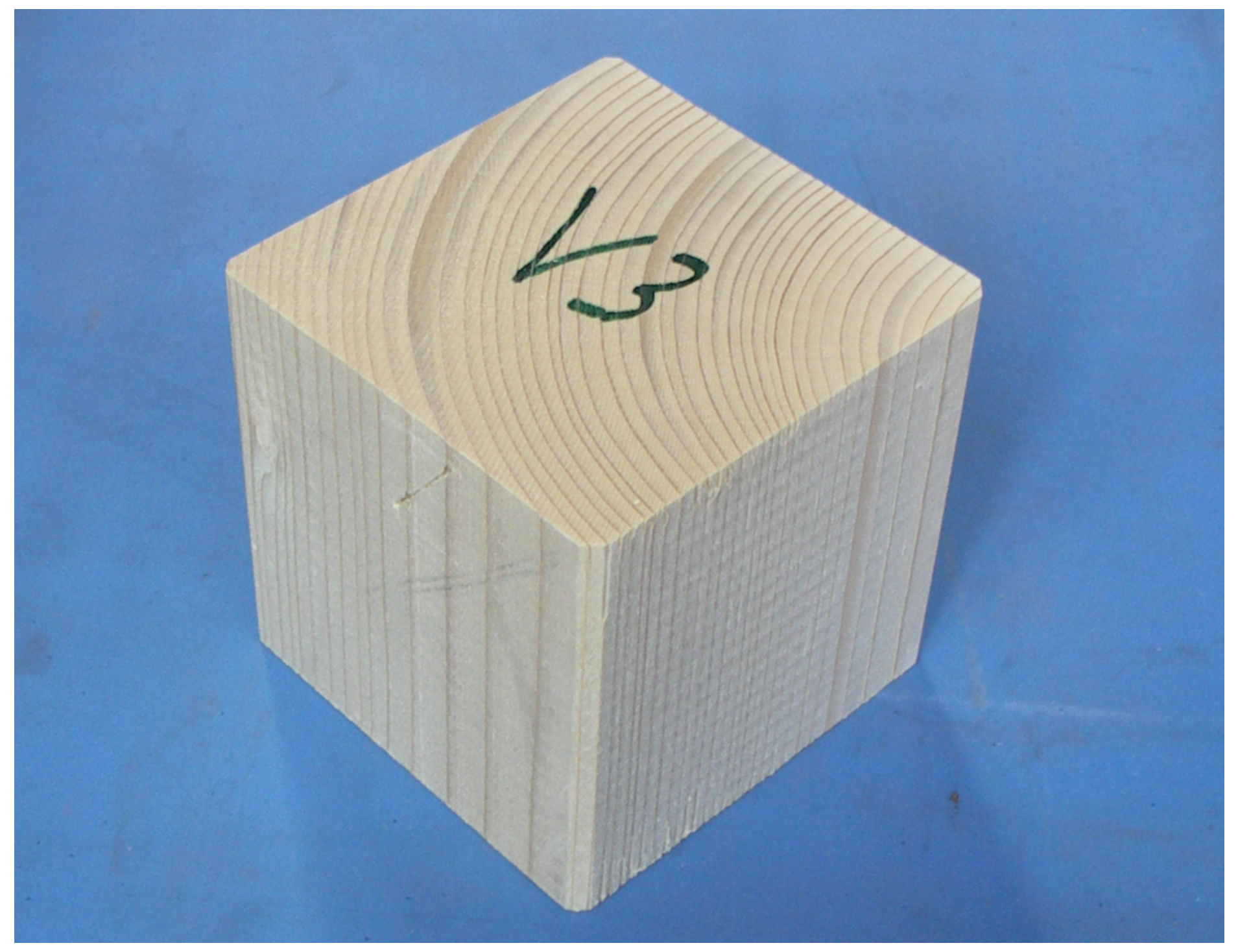

Fig 06 


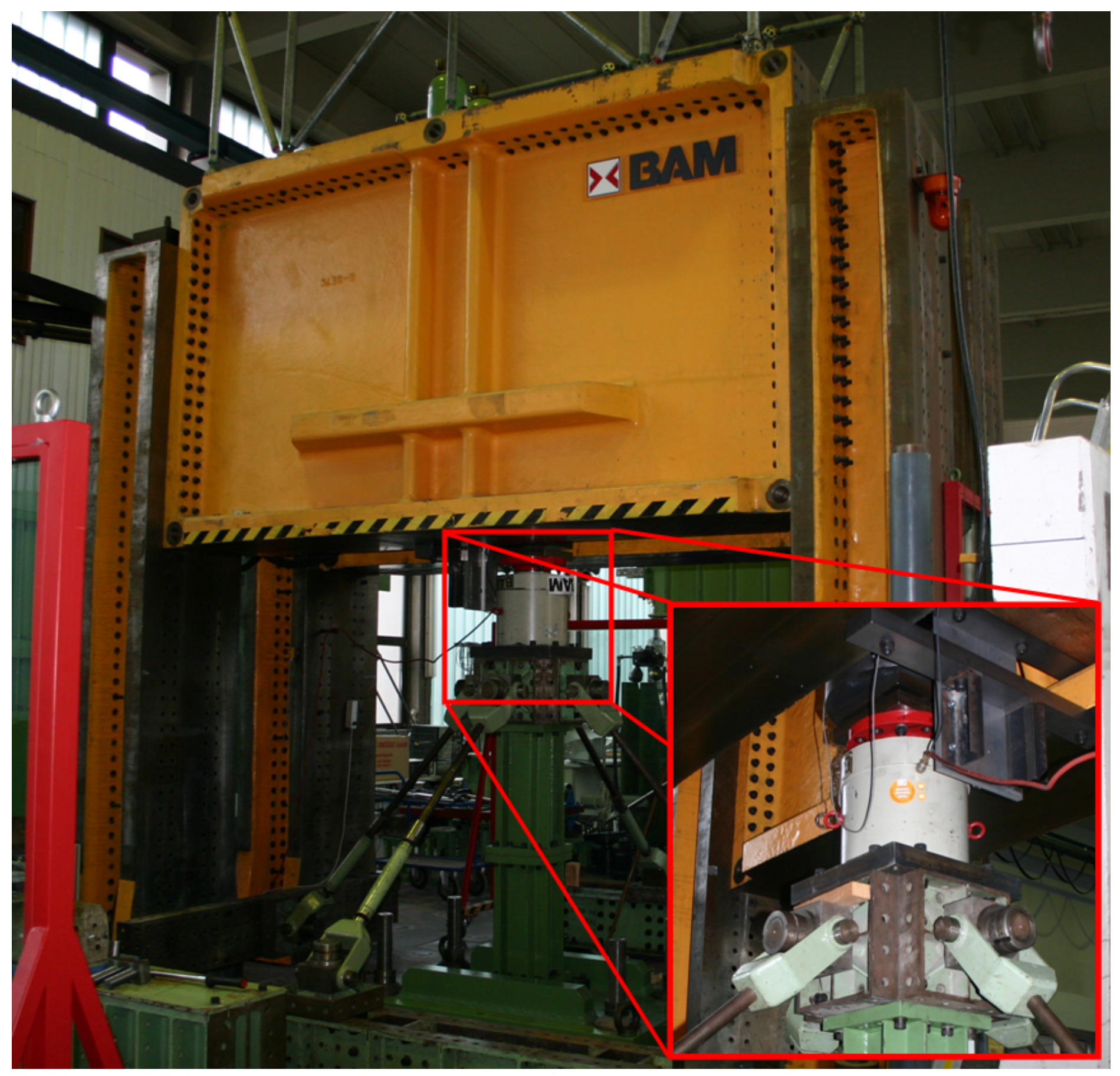




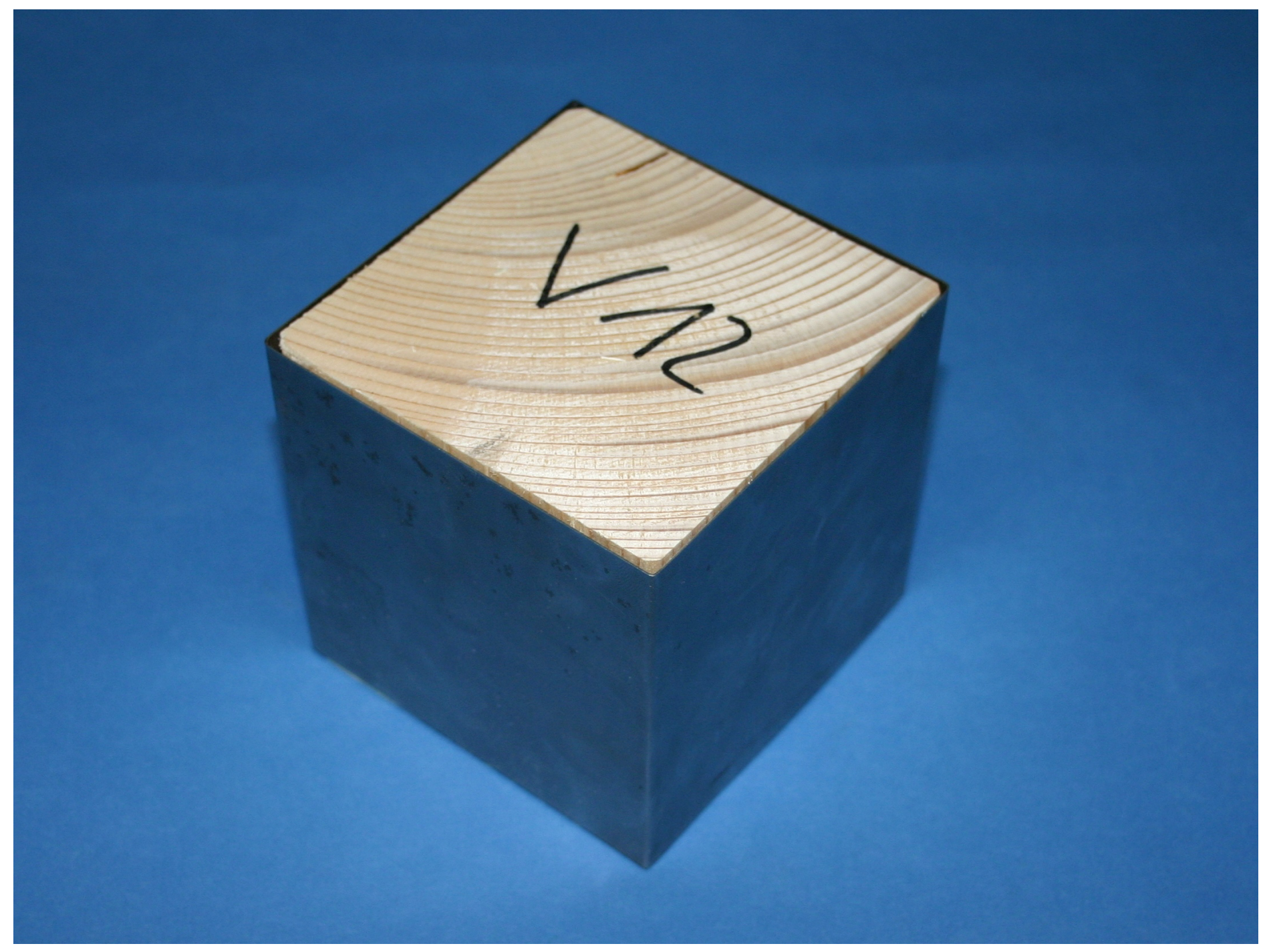

Fig 08a 


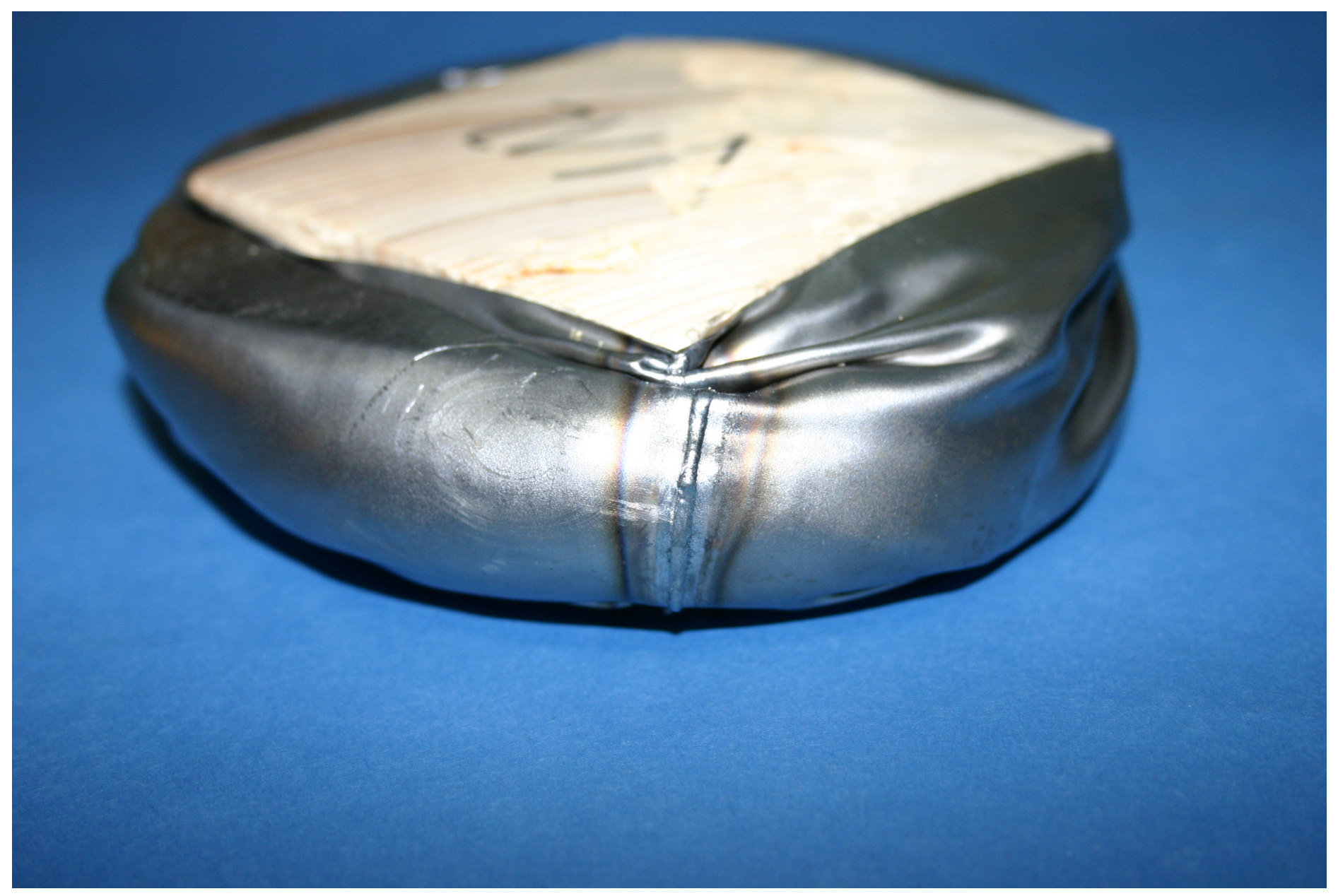

Fig 08b 


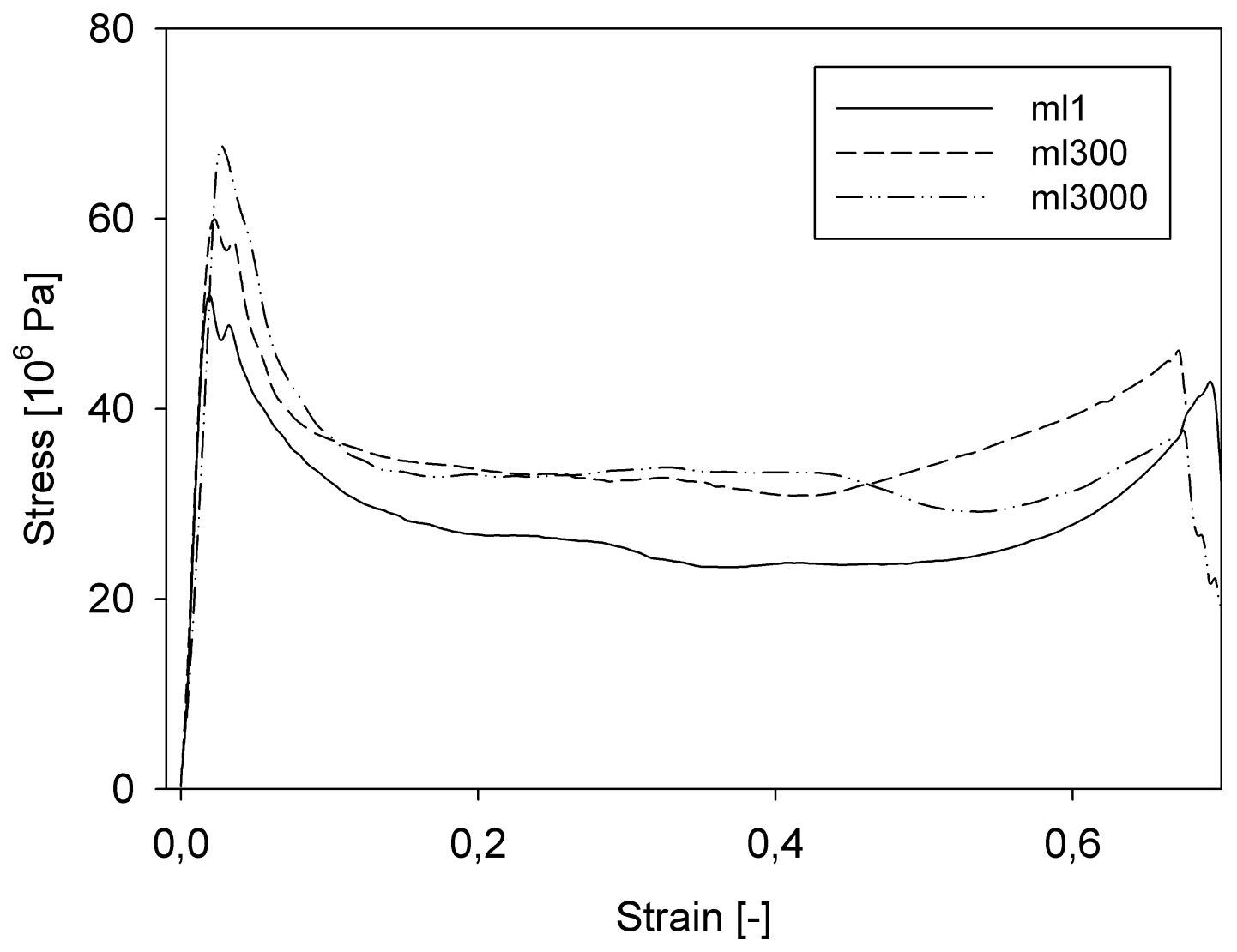




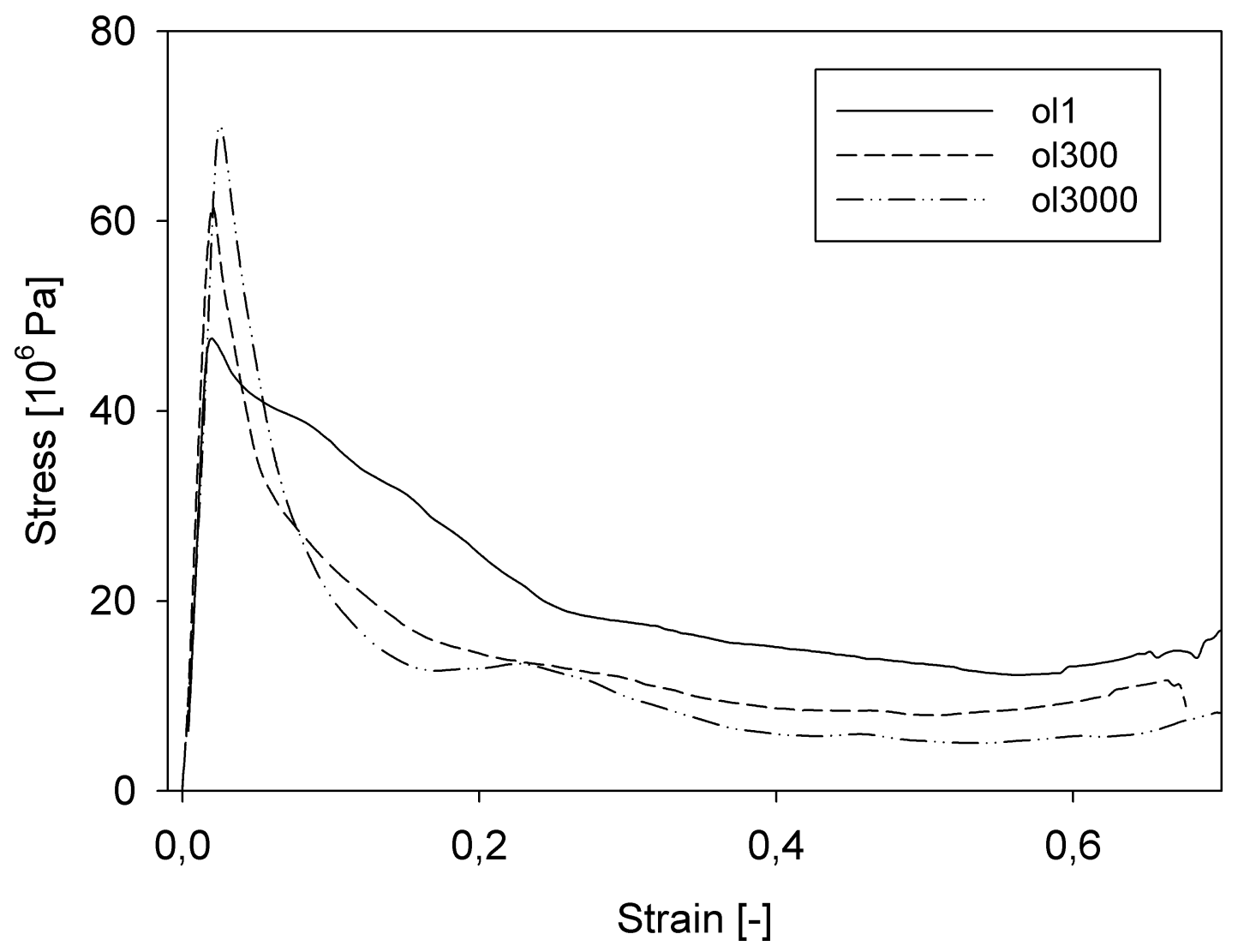




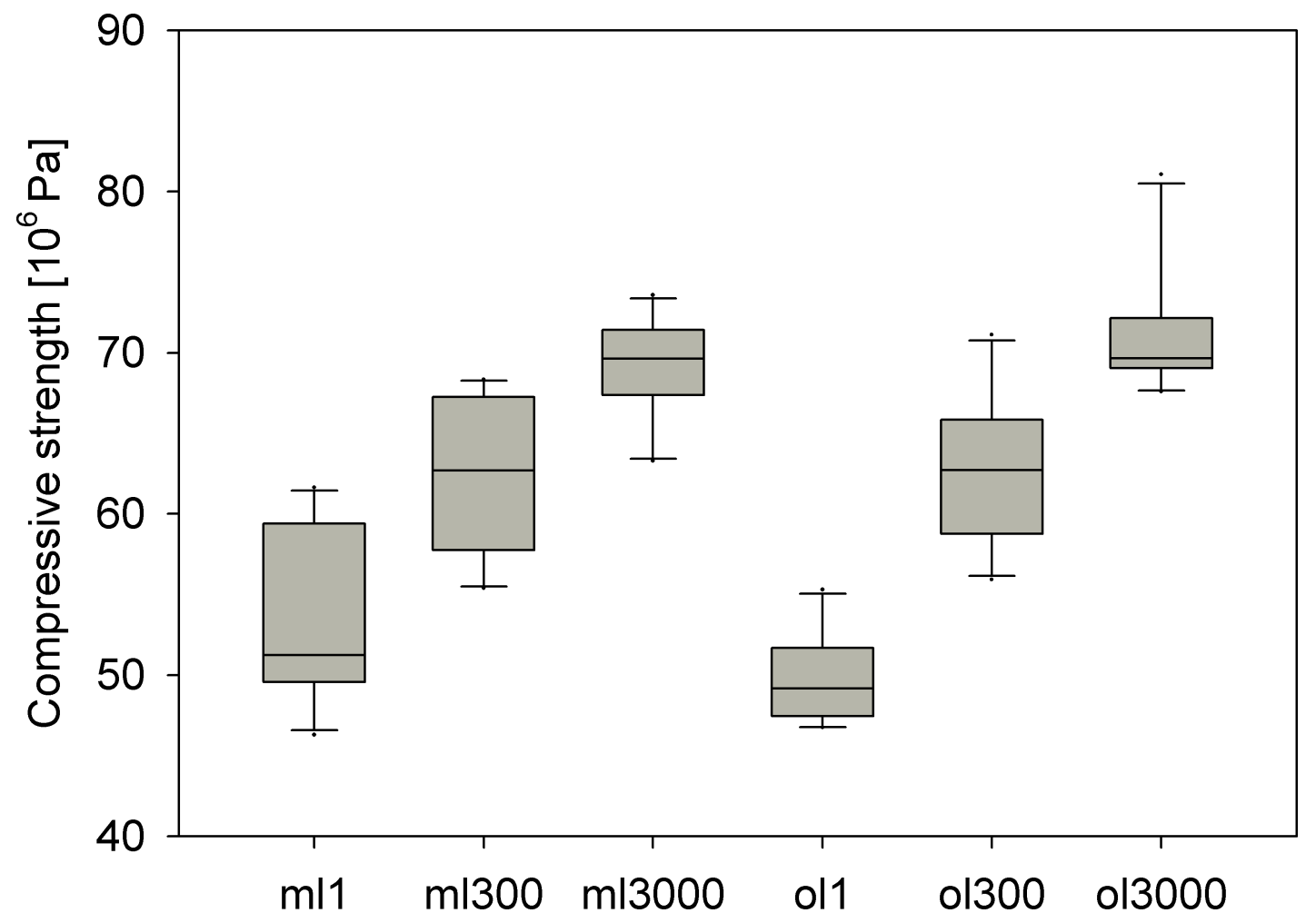

Fig 10 


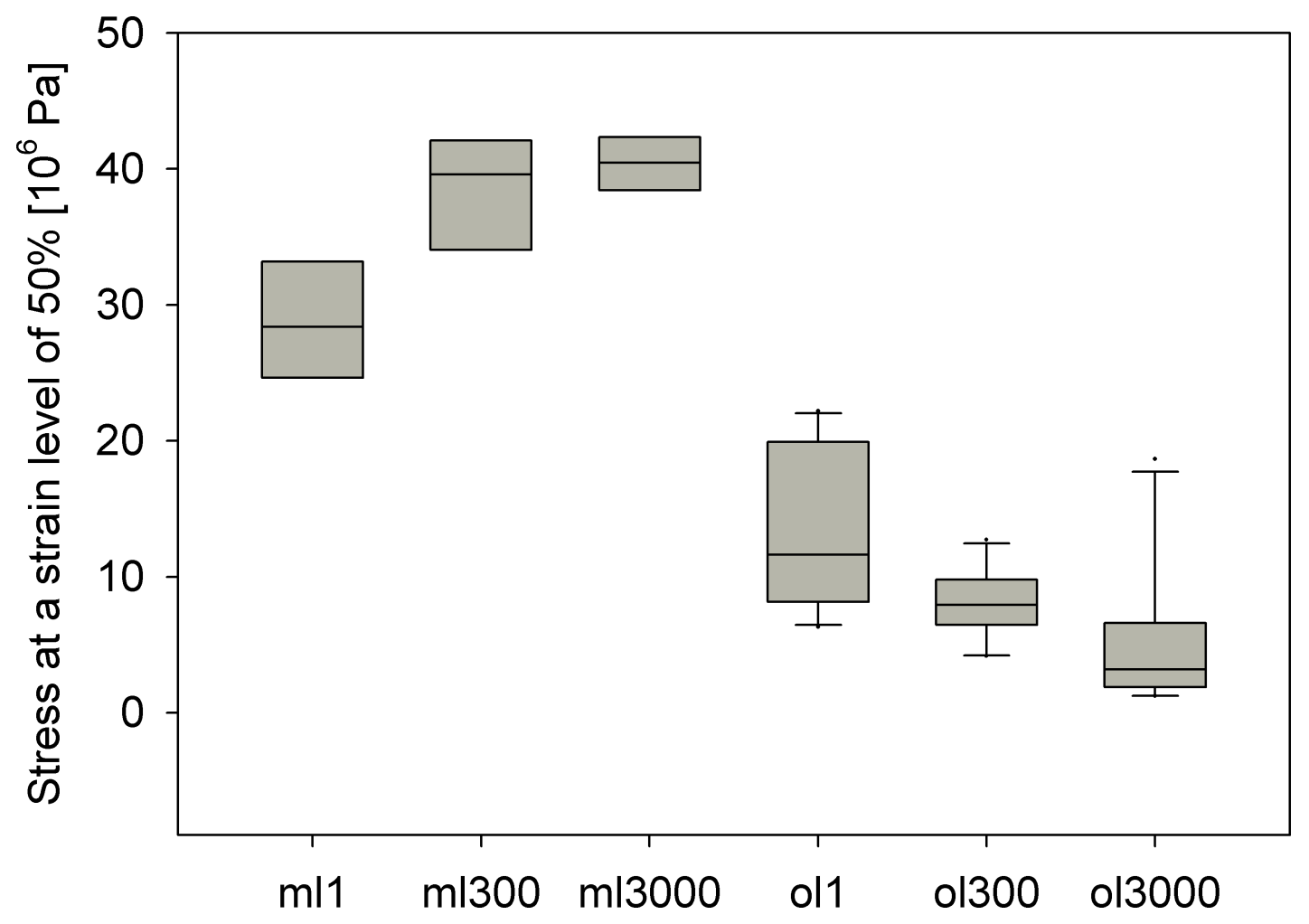




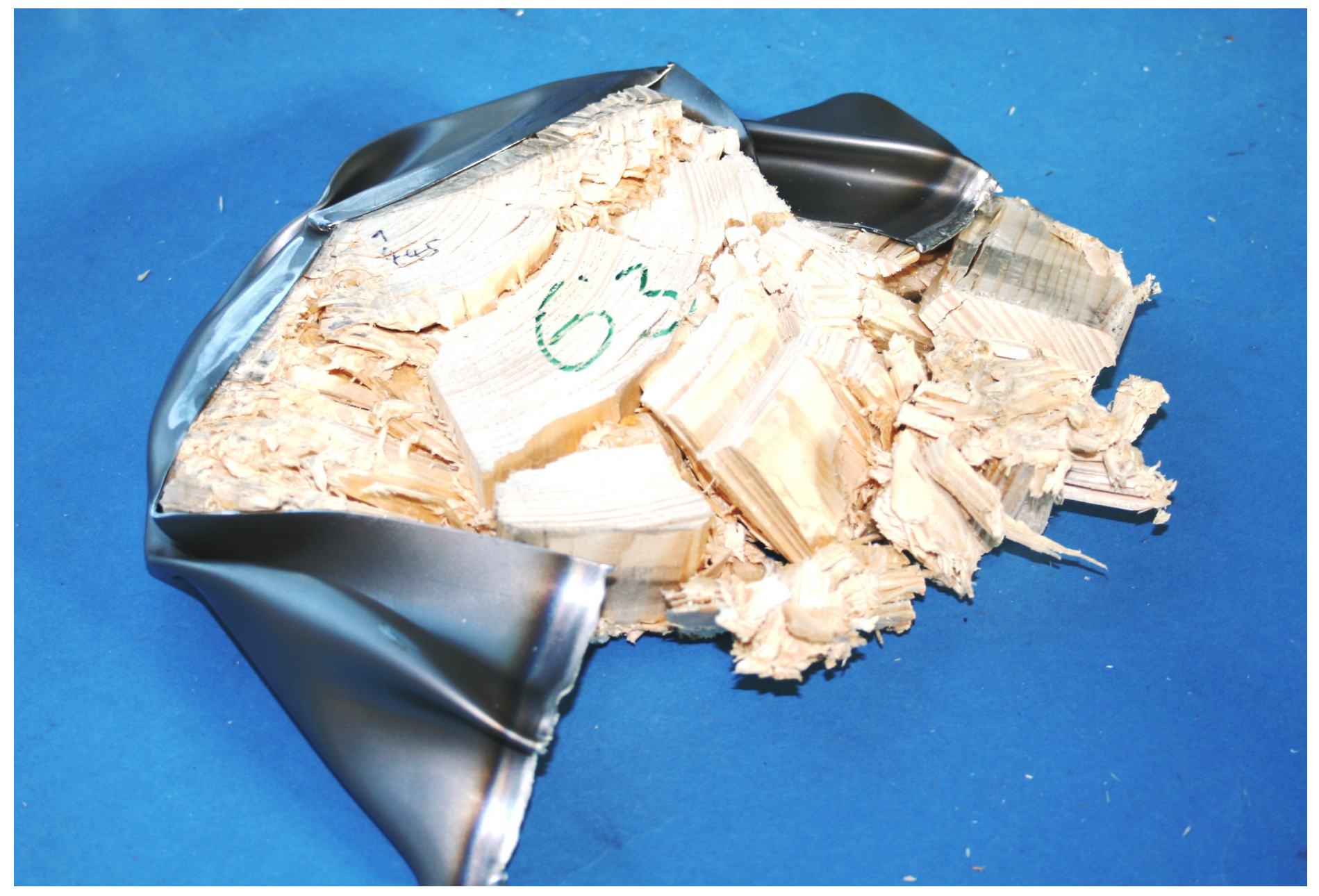

Fig 12 


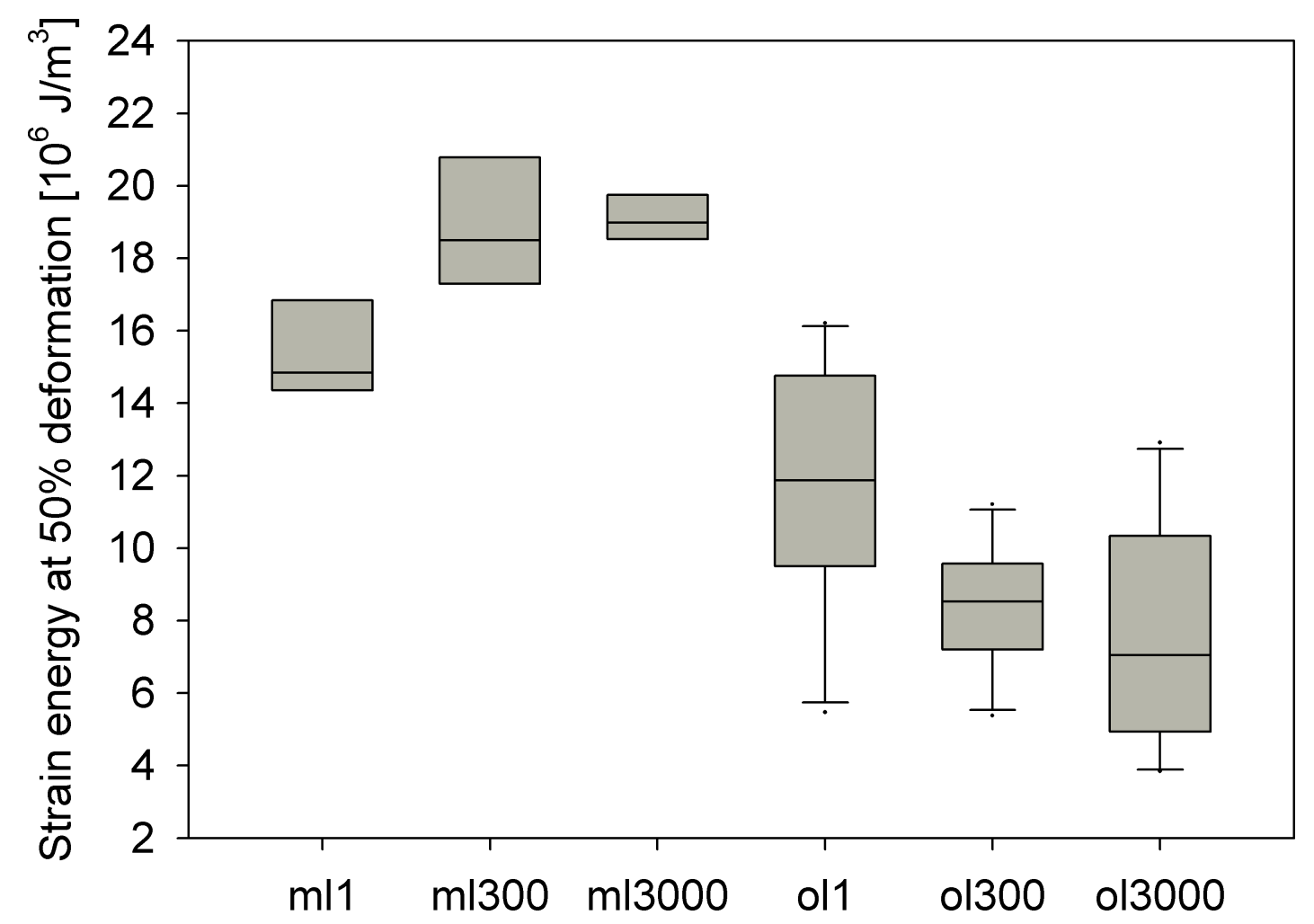

